University of Nebraska - Lincoln

DigitalCommons@University of Nebraska - Lincoln

Karl Reinhard Papers/Publications

Natural Resources, School of

2019

Imaging coprolite taphonomy and preservation

Karl Reinhard

Morgana Camacho

Breyden Geyer

Samantha Hayek

Chase Horn

See next page for additional authors

Follow this and additional works at: https://digitalcommons.unl.edu/natresreinhard

Part of the Archaeological Anthropology Commons, Ecology and Evolutionary Biology Commons, Environmental Public Health Commons, Other Public Health Commons, and the Parasitology Commons

This Article is brought to you for free and open access by the Natural Resources, School of at DigitalCommons@University of Nebraska - Lincoln. It has been accepted for inclusion in Karl Reinhard Papers/ Publications by an authorized administrator of DigitalCommons@University of Nebraska - Lincoln. 
Authors

Karl Reinhard, Morgana Camacho, Breyden Geyer, Samantha Hayek, Chase Horn, Kaitlin Otterson, and Julia Russ 


\title{
Imaging coprolite taphonomy and preservation
}

\author{
Karl Reinhard, ${ }^{1}$ Morgana Camacho, ${ }^{1}$ Breyden Geyer, ${ }^{2}$ \\ Samantha Hayek, ${ }^{3}$ Chase Horn, ${ }^{4}$ Kaitlin Otterson, ${ }^{2}$ \\ \& Julia Russ 5
}

\begin{abstract}
1 School of Natural Resources, University of Nebraska-Lincoln, Lincoln, NE
2 Forensic Science Program, University of Nebraska-Lincoln, Lincoln, NE

3 University of Nebraska State Museum, University of Nebraska-Lincoln, Lincoln, NE

4 Department of Anthropology, University of Nebraska-Lincoln, Lincoln, NE

5 Morrison Microscopy Core Research Facility, Center for Biotechnology, University of

Nebraska-Lincoln, Lincoln, NE
\end{abstract}

Correspondence: Karl Reinhard, kreinhard1@unl.edu

ORCID http://orcid.org/0000-0003-1653-9329 (K. Reinhard)

\begin{abstract}
The impact of coprolite taphonomy on parasite remains and aDNA recovery has been recognized. In general, coprolites from sites protected by geologic features such as caves and rock shelters exhibit the best preservation. In contrast, coprolites from open sites can be badly affected by taphonomic processes as shown by analyses of parasite eggs. For eggs, the impact of mites and free living nematodes has been quantified. Mites are associated with poor pinworm egg preservation. In other studies, percolation of water through sediments has a negative impact on egg recovery. We note that dietary remains can also decompose at open sites. Through scanning electron microscopy (SEM), we present examples of screened but chemically untreated microscopic remains. "Panorama" SEM images provide an excellent visual overview of the taphonomy of dietary remains. For this study, our focus is on
\end{abstract}

Published in Archaeological and Anthropological Sciences (2019) 11:6017-6035

doi:10.1007/s12520-019-00946-w

Copyright (C) 2019 Springer-Verlag GmbH Germany, part of Springer Nature. Used by permission.

Submitted 31 December 2018; accepted 27 September 2019; published 20 November 2019 
Southwestern coprolites as a demonstration of diversity within a single region. Examples from caves and rock shelters were examined first to describe the taphonomic challenges for protected sites. Then, attention was turned to coprolites from open sites. In general, the challenges noted for parasite preservation are seen for other microfossils. However, the preservation of lignin, sporopollenin, calcium oxalate, and siliceous microfossils is generally better than cellulose structures. These observations are relevant to the selection process of samples for aDNA analysis and immunological study. This is especially relevant for the gut microbiome since decomposer fungi and bacteria molecular signals could be recovered in metagenomic analysis.

Keywords Scanning, electron, microscopy, Coprolite, Microfossils, Imaging, Taphonomy

Our goal is to present the taphonomic processes of decomposition within coprolites. This is progressively more important as molecular analyses are increasingly applied to samples (Tito et al. 2008, 2012). Because molecular analyses are expensive, especially the metagenomic approach to defining ancient gut microbiomes, there is value to characterizing the levels of decomposition manifest in any sample of interest. Samples that are highly decomposed can be put on low priority relative to ideal preservation for costly specialized analyses. Characterizing the level biological activity can provide evidence towards additional genetic sequences that have decomposer origins.

The value of coprolite data has increased over the last decades. Because of increased interest in evolution of gut microbiome and applications to Type II diabetes, Bryant and Reinhard et al. (2012) designated coprolites as the "missing links" to understanding human health. ELISA (enzyme-linked immunosorbent assay) methods have been used to identify immunological residues (Gonçalves et al. 2002; Marlar et al. 2000; Morrow and Reinhard 2016). In addition, lessons from prehistory can be used in the development of modern, sustainable food production (Denevan 1995; Isendahl and Smith 2013). Coprolites are the best source of subsistence data from the perspective of quantification of the consumption of plant foods. Therefore, they should be a source of foundational data for analysis of food use systems. However, not all coprolites have the same information potential. As we move forward into a new period of molecular and biochemical study, we need to assess the impact of taphonomy on information potential of coprolite samples. It is our purpose to demonstrate the range of postdepositional conditions that affect microremains. 
Taphonomic conditions affect the preservation of coprolite components. For example, research showed that parasite eggs preserved less well in open sites compared to shelter or cave enclosed sites (Reinhard 1992; Reinhard and Clary 1986). Specific studies assessing parasite egg taphonomy defined the influences of site formation on parasite egg preservation (Morrow et al. 2016; Rácz et al. 2015). Specifically, five sets of factors affect parasite eggs: abiotic, contextual, anthropogenic, organismal, and ecological. Abiotic refers to temperature, soil, pH, humidity, and other non-living factors (Morrow et al. 2016). Contextual refers to the archeological source materials that have inherent differential preservation potential such as mummies in contrast to sediments or coprolites. Anthropogenic refers to the human actions that could influence preservation, from deposition to collection and transportation for final analysis. Organismal refers to biological characteristics of specific parasite structure and biology such as egg resistance, fecundity, and life cycle. For dietary remains, some composition types, such as crystalline phytoliths, sporopollenin, and lignin, enhance resistance to decomposition. Ecological refers to the decomposer organisms that are part of the environment from which the archeological material came from. We are applying four of five categories of preservation to assess preservation potential of dietary remains from coprolites. The organismal category is specific to parasite resistance and cannot be applied to general qualities of sample preservation.

Camacho et al. (2016) documented the destruction of parasite eggs in various archeological contexts. They found that modern parasite eggs, when added to Brazilian shellmound sediments, decomposed nearly completely in 45 days. Camacho then turned her attention to the American Southwest (Camacho et al. 2018a). She found that decomposer organisms proliferated in open sites at the time they were occupied. This resulted in negative taphonomic outcomes for coprolites from open sites (Camacho et al. 2018a). Microscopically, decomposers include free-living nematode worms, mites, and fungi. Macroscopic decomposers include insects. When decomposers were quantified and compared to parasite results from the samples, it was demonstrated that mites have the most pronounced impact on parasite eggs (Camacho et al. 2018a). 


\section{Materials and methods}

The University of Nebraska-Lincoln, School of Natural Resources Pathoecology Laboratory curates hundreds of coprolite samples analyzed during the career of the senior author. In addition, on-going analyses of sites is adding even more samples to the collection. We are reviewing some of these samples to illustrate the value of interdisciplinary analysis of botanical, faunal, and mycological components.

Which specimens are of human origin? This is a common question and has been addressed repeatedly since Fry's (1977) first large-scale analysis of coprolites from Utah. A review by Reinhard (2017) summarizes all details of human origin determination from contextual analysis to aDNA evaluation. More recently, the determination of human origin was reviewed (Taylor et al. 2019). For human identification, the morphologies of the specimens must be of sufficient size and shape to fall within the range of variation for human coprolites (Bryant and Reinhard 2012; Taylor et al. 2019). For initial rehydration in 0.5\% trisodium phosphate solution, the solution color must be consistent with human coprolites (Fry 1977; Holden 1990; Taylor et al. 2019). Human coprolites generally result in an opaque dark brown to black solution. Other mammals produce solutions of light shades of translucent yellow. Parasitological analysis can result in the recovery of dog-specific and human specific helminth species. The presence of these parasites is an important biomarker of human origin (Camacho et al. 2018a; Fugassa et al. 2011; Jiménez et al. 2012). Finally, full dietary analysis is essential in demonstrating human origin (Taylor et al. 2019). We considered all of these details of human origin in the analysis of the coprolites described herein. We are confident that all samples described below are human.

We have divided the samples into good, fair, and poor preservations categories depending on the relative preservation of dietary remains. We are also considering the level of sample infestation with free-living nematodes and arthropods. The sites of Bighorn Cave, Dust Devil Cave, Hinds Cave, and Turkey Pen Ruins offered examples of good preservation. Fair preservation is represented by samples from room 225 and an East Ruin kiva of Aztec Ruins. Poor preservation is exemplified by samples from room 219 of Aztec Ruin (Camacho et al. 2018a). It is noteworthy that the samples from an open site, Aztec Ruin, exhibit diminished preservation. 
In general, processing coprolites does not require hydrofluoric and hydrochloric acid treatments. This is because coprolites rarely have high silica or calcium carbonate content. Most coprolites from caves respond to rehydration solutions. For pollen concentration, acetolysis is necessary. For this analysis, fine silica sand was very abundant in Aztec Ruins coprolites. Therefore, a hydrofluoric acid treatment was necessary. Importantly, we are presenting images of rehydrated and screened remains prior to hydrofluoric acid and acetolysis procedures. We have noticed during years of parasite analysis that botanical structures evident before acetolysis are gone afterwards. Phytoliths are abundant in samples before hydrofluoric acid treatment but are nearly absent after treatment. Therefore, a second goal of this study is the illustration of the diversity and abundance of microfossils that can be concentrated and quantified immediately after rehydration and disaggregation without chemical processing.

Archived samples from the senior author's graduate research are divided into rehydrated and screened samples that were prepared for parasitological study (Reinhard 1985, 1988). These samples were dried from alcohol for long-term storage in 1989. For the SEM analysis of Bighorn Cave, Dust Devil Cave, and Hinds Cave, dried remains from storage vials were used. A subsample of these remains was processed for palynology, and those samples are stored in glycerin. Samples from Aztec Ruins were brought to the lab and processed in 20162017. The remains are part of Great House Diet and Parasitism Project that focuses on both Salmon Ruin and Aztec Ruin. The parasitological data for both sites have been published (Camacho et al. 2018a). The dietary reconstruction is ongoing. In addition, samples from Turkey Pen Ruin are under current analysis as part of a larger project focusing on Basketmaker II and III sites.

We imaged screened material from coprolites after rehydration and screening. The methods applied in the UNL Patholecology Lab are derived from the Callen method as summarized by Camacho and her colleagues (Camacho et al. 2018b). The samples are individually described, cleaned by brushing, photographed, and weighed. The samples are subsampled, ideally by sectioning the sample longitudinally. For each sample, one portion is preserved for future analysis and the second portion is processed. The interior of the longitudinal half is processed for analysis. The subsamples are rehydrated in $0.5 \%$ trisodium phosphate aqueous solution for $48 \mathrm{~h}$. Then, the samples are 
transferred into beakers on stir plates and disaggregated using a stir bar. Disaggregation continues until the microscopic particles are completely separated from macroscopic fibers, bones, and seeds. The disaggregated remains are poured through $250-\mu \mathrm{m}$ mesh screens over a second series of beakers. Using distilled water jets from wash bottles, the macroscopic samples are washed while being separated with laboratory minispatulas and glass stir rods. The separated remains pass through the screen. In this way, the microscopic remains are separated from the macroscopic remains. Microscopic remains are smaller than $250 \mu \mathrm{m}$, and macroremains are larger than $250 \mu \mathrm{m}$.

For quantification, at the end of the 48-h rehydration period, one Lycopodium spore tablet was added per gram of coprolite. Lycopodium spore tablets are available from the University of Lund, Sweden. The tablets are dissolved in 1- 5\% $\mathrm{HCl}$ and added to the rehydrating coprolites. These spores mix with the samples during the disaggregation phase. The concentration of microfossils per gram are then estimated by dividing the number of microfossils counted by the number of $L y$ copodium spores counted. This quotient is multiplied by the number of spores added and then divided by the weight of the subsample (Camacho et al. 2018b). The coprolites from Aztec Ruin exhibited some calcium carbonate mineralization. To dissolve the calcium carbonate, 200 $\mu \mathrm{l}$ of $40 \%$ of hydrochloric acid $(\mathrm{HCl})$ was added to the samples as they were disaggregated in $300 \mathrm{ml}$ of distilled water.

For scanning electron microscopy (SEM), $30 \mu \mathrm{l}$ of the prepared samples were transferred to microcentrifuge tubes ( $1.5 \mathrm{ml}$ volume) in $100 \%$ ethanol. These samples were washed four times in 100\% ethanol. These were transferred to the Morrison Microscopy Core Research Facility. For SEM preparation, $\sim 30 \mu$ of sediment were pipetted and placed onto a $10 \mathrm{~mm} \times 10 \mathrm{~mm}$ polycarbonate membrane (200-nm hole size) on a paper filter. After air-drying for 2-3 min, each of the membranes was placed onto a double-sided adhesive conductive tab on an SEM sample mounting stub. The samples were further dried at $42{ }^{\circ} \mathrm{C}$ in a sample oven overnight before being sputter coated with a thin layer of chromium ( $~ 5 \mathrm{~nm}$ thick) using a Denton Vacuum Desk V sputter coater. Samples that were already processed and dry from Dust Devil Cave, Bighorn Cave, and Hinds Cave were placed directly on conductive tabs on labeled SEM sample mounting stubs. Any excess sample was removed with canned air, and stubs were further dried at $42{ }^{\circ} \mathrm{C}$ before sputtercoating. All samples were examined on a Hitachi 
S-470o Field Emission SEM, and images were collected at different magnifications $(\times 1000$ to $\times 5000)$.

We are presenting images of microscopic remains recovered from the screening process. We find that the condition of the remains reveals the general taphonomic conditions of coprolite samples.

\section{Good preservation-sheltered sites}

\section{Hinds Cave, Lower Pecos Canyonlands, Texas}

The archeology of the Lower Pecos Canyonlands has benefited from specialized analyses. Rock art study (Boyd and Cox 2016) demonstrated symbolic and mythological affinity between the ancient Lower Pecos inhabitants and indigenous peoples of Mexico. This interpretation was supported by aDNA analysis of human remains (Raff et al. 2018). The region was one of the first foci for aDNA analysis of food and medicinal plants (Poinar et al. 2001; Reinhard et al. 2008) and steroid analysis (Sobolik et al. 1996). Analysis of dog aDNA from a Hinds Cave human coprolite defined the placement of Holocene dogs in overall canid phylogeny (Tito et al. 2008). These studies were successful and suggested that the samples from Hinds Cave were ideal for biochemical analysis. However, previous microbiome research recovered enigmatic data (Tito et al. 2008, 2012). Therefore, the site taphonomy may challenge metagenomic approaches. For this reason, we first examined a Hinds Cave to assess a typical coprolite for taphonomic changes.

The Lower Pecos Canyonlands is a region of excellent preservation of hunter-gatherer archeology. Yet, compared to the other coproliterich regions of the Great Basin and Colorado Plateau, the archeology of the area is not widely cited. Thus, it is worthwhile to present some key references to our readers. This region of Coahuila and Texas centers on the confluences of the Rio Pecos and Devils River with the Rio Grande. The numerous rock shelters resulted in the preservation of deep archeological record that extends over ten millennia. The preservation of rock art and portable art provides insight into mythology and ritual (Boyd 2013; Boyd and Cox 2016; Hampson 2016; Kirkland and Newcomb 1996; Shafer 2013; Turpin 1996) and also portable art (Shafer 1975) some associated with women (Mock 2013). There is a 
comprehensive record of dietary plants (Riley 2008, 2010) and animal foods (Reinhard et al. 2007; Lord 1984). The evolution of hallucinogens and medicines is documented by plant remains (Boyd and Dering 1996). Woven art and basketry are well represented in the sites (McGregor 2013). It also has a record of diet derived from coprolites (Riley 2008, 2010) and cooking features (Black and Thoms 2014; Koenig 2012) spanning 8900 to 1300 years ago. Thus, there is probably no region in the Americas with a more superlative preservation of huntergatherer art, technology, and subsistence.

A wide spectrum of food was available to Lower Pecos hunter-gatherers. However, coprolite evidence shows that Archaic people focused their subsistence on a limited range of dessert succulents and bulbs. In Riley's (2010) review of ethnographic data and coprolite analyses, 22 taxa of plants were used for seeds, fruits, pods, nuts, bulbs, caudices, and cladodes. Caudices of Agave and sotol (Dasylirion) were a key food source in winter and spring. Prickly pear (Opuntia) cladodes (pads) were heavily harvested in spring and summer. Mesquite (Prosopis) pods were a key resource in summer and fall. Prickly pear fruit was a mainstay in spring and summer. The key food preparation technology was earth oven cooking or pit baking (Black and Thoms 2014; Koenig 2012). Sotol, Agave lechuguilla, and wild onions (Allium) were prepared in these ovens. Coprolite analysis revealed a strong reliance on sotol, agave, and prickly pear (Riley 2008).

To illustrate the typical residue from Lower Pecos Canyonland coprolites, we selected microscopic residue from Hinds Cave sample 7 from the Pathoecology Laboratory archived collections. This coprolite was recovered from Hinds Cave (41VV456) B-1, Lens 5 dating between 2560 and $2810 \mathrm{BC}$. and was analyzed as part of the senior author's dissertation (Reinhard 1988). Fly puparia of the genus Fannia were present in the coprolite. This suggests that latrine flies were decomposers. The images from this screened residue show that the preponderance of identifiable material is composed of calcium oxalate phytoliths (Fig. 1). The phytoliths are from cactus and Agave. There was a health impact of consuming so much abrasive, biogenic material in the diet. Danielson and Reinhard (1998) calculated that 10-20\% of the microscopic residue from coprolites was composed of phytoliths, as illustrated in Fig. 1. They reviewed the existing evidence of dental pathology for the Lower Pecos Canyonlands. That review revealed that dental microwear led to dental abscessing and premortem tooth 


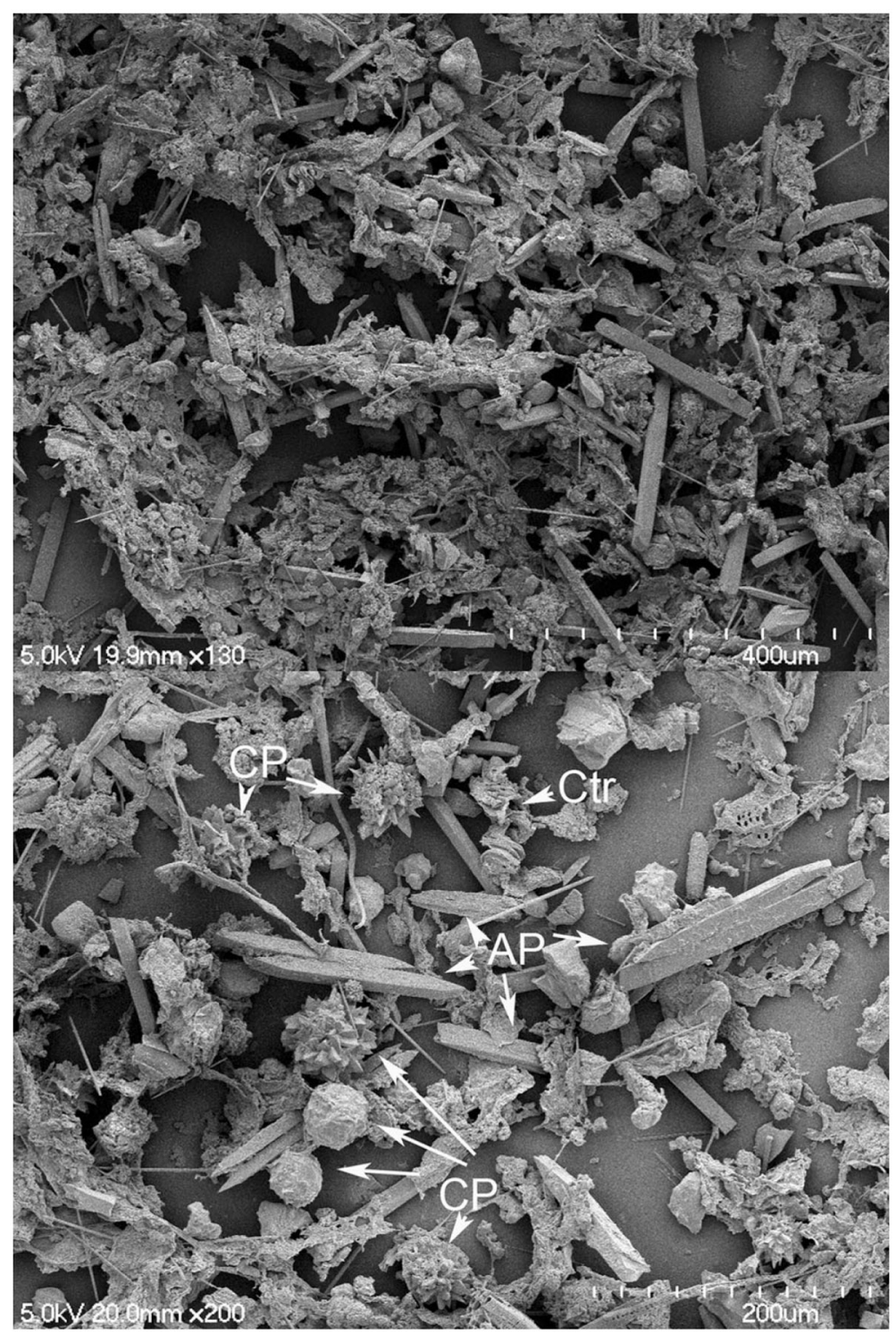

Fig. 1 The upper image shows screened microremains of Lower Pecos Canyonland coprolites show an impressive amount of desert succulent phytoliths, primarily from Agave, but also from cacti. These remains result from chewing Agave leaf base quids, a dietary tradition that resulted in microwear, abrasion and eventually abscesses. The lower image shows the contrast between Agave phytoliths (AP) and cactus (Opuntia) phytoliths (CP). Not the presence of cactus tracheids (Ctr) from eating prickly pear pads. This represents good preservation because of the generally clear separation of micro remains. 
loss. This was the main paleopathological condition noted in human remains from the area. These researchers demonstrated that calcium oxalate phytoliths are harder than dental enamel and demonstrated that parallel striations on tooth enamel were equidistant to the separation of phytoliths in Agave caudices. Therefore, the prehistoric diet of desert succulents, rich in phytoliths, was the main cause of edentulism in young adults in the region. Reinhard and Danielson (2005) expanded this study to other cultural regions. They found that reliance on desert succulents put people at dental disease risk across the Southwest cultural region.

A similar conclusion was reached by Hammerl et al. (2015) for a population in Durango, Mexico, who were partly dependent on Agave. Figure 1, therefore, not only depicts a common dietary component for the Chihuahuan desert, but also a pathogenic dietary abrasive for the region. Reinhard and Araujo (2015) connected earth oven facilities with the spread of Trypanosoma cruzi infection which was a source of Chagas disease in the region. Thus, preparation of desert succulent caudices had considerable pathological impact in the area.

SEM analysis of the coprolite (Fig. 1) shows additional details of preservation that may hint at the activity of decomposers. Scattered across the phytoliths, lignin rings, and cellulose fibers are encrustations of morphologically unrecognizable particles. These are not unlike the material seen in coprolites that support a rich decomposer community as discussed below for Aztec Ruins sample 18. Gut microbiome researchers included coprolites from Hinds Cave in a pioneering analysis (Tito et al. 2012). They found that the sequences from Hinds Cave samples showed little similarity to known gut microbiomes and failed to compare well to any source environment. We conclude that although Hinds Cave samples show excellent preservation of all kinds of durable botanical and animal remains, the samples may have remained moist long enough to attracted decomposers such as flies and perhaps microbial organisms as well. Thus, the gene sequences were potentially altered by invasive organisms.

\section{Turkey Pen Ruin, Utah}

Turkey Pen Ruin is a Basketmaker II (BMII) site. Coprolites from this site have been analyzed by several researchers since the 1980 s as reviewed by Battillo (2017, 2018). The samples were directly dated 


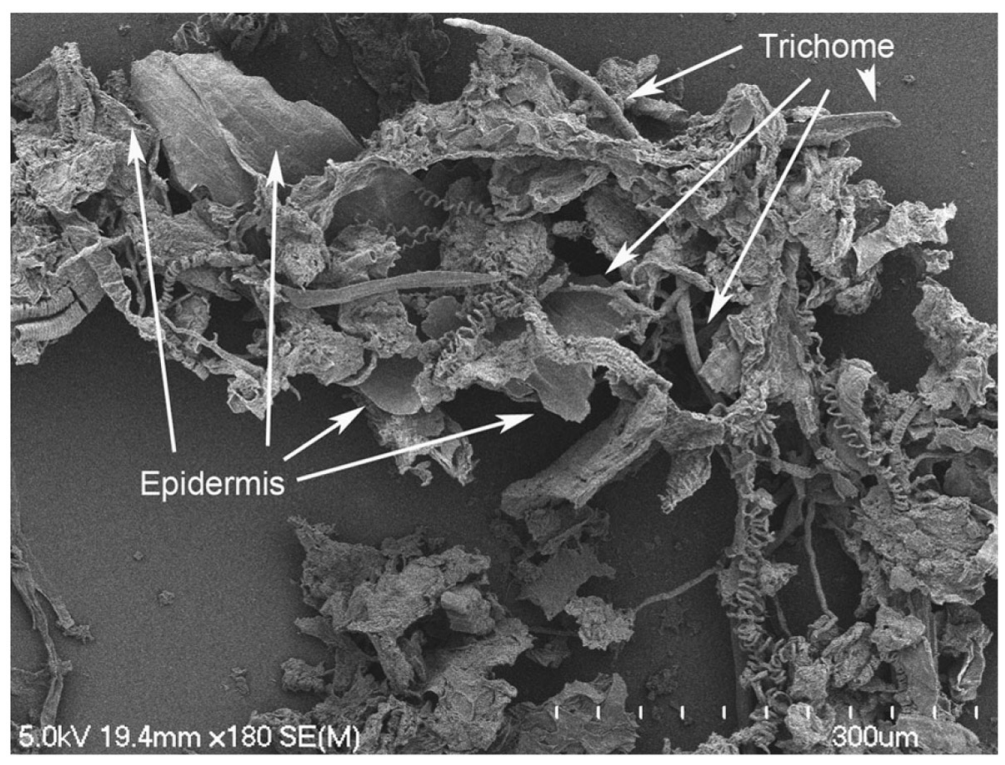

Fig. 2 This image shows excellent separation of microfossils from a Turkey Pen Ruins coprolite. Clearly visible are spiral tracheid secondary thickenings and fiber cells from xylem vascular bundles. These are over and under sheets of plant epidermis. Harder to discern are obscured sections of complex branching trichomes.

by Battillo to $\mathrm{AD} 73$ to $\mathrm{AD} 181$ calibrated (Battillo 2018:127, Appendix A). The site is very important for understanding the foundations of subsistence for Ancestral Pueblo peoples. Summarizing from Battillo (2017), Turkey Pen Ruin demonstrates the maize-reliant subsistence typical of BMII. Up until her analysis, it appeared that Turkey Pen Ruin occupants were challenged to obtain essential amino acids since previous analyses indicated an absence of beans and meat in the diet. Thus, Battillo defined the site as ideal in understanding the evolution of the Ancestral Pueblo agriculture. She specifically explores how the people who used Turkey Pen Ruin supplemented their diet with plant and animal remains. To accomplish this, she applied molecular analysis for plant and animal aDNA. She also explored mycological study to assess fungal components of diet. Wild plant foods included pine nuts (Pinus edulis), purslane (Portulaca) leaves, yucca caudices/ possible fruit/buds, squash (Cucurbita pepo) seeds/pollen, and cheno-am seeds/pollen. Cheno-am refers to species in the family Amaranthaceae and the subfamily Chenopodioideae. She was able to show meat consumption via bone and molecular analysis. Finally, she was able to demonstrate the nutritional importance of maize truffles in the diet. 


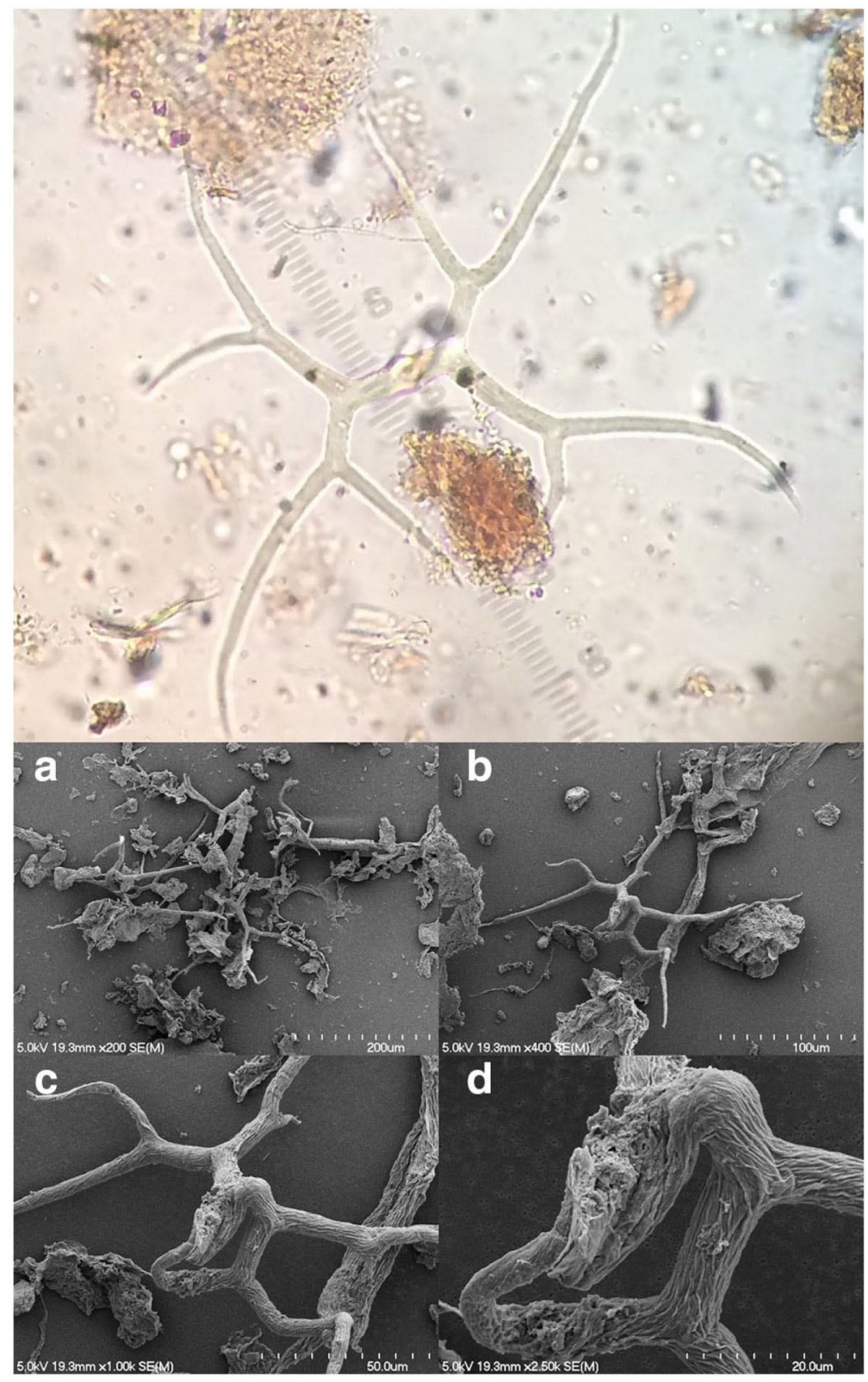

Fig. 3 These light microscope and SEM images shows the intriguing branching trichomes observed in Turkey Pen Ruins coprolites. The overall symmetry suggests an origin with mustard leaves. The upper image shows a light microscope image of a trichome separated from other food debris. The SEM images reveals that most mustard trichomes were entangled with each other and other plant debris (A). B-D show an isolated trichome at various magnifications. Of the mustard family genera that could have been used at the site, these images are most consistent with species of Boechera (rockcress) or Descurainia (tansymustard), but not Lepidium (pepperweed). 
Our on-going analysis of seven samples from this site, curated to the Pathoecology Laboratory, showed good separation of rehydrated microfossils (Fig. 2). The samples contained unusual, antler shaped structures consistent with dendritic trichomes (Fig. 3). Light microscopy revealed these to be composed of lignin, sometimes attached to plant epidermal cells. Using SEM, we were able to determine that these trichomes are characteristic of leaves from the mustard family. Comparing the morphology of Turkey Pen Ruin trichomes with published review (Beilstein et al. 2008), we conclude that this unusual trichome type is from mustard leaves, either species of rockcress (Boechera) or tansymustard (Descurainia), but not pepperweed (Lepidium) (Fig. 3). The genera Descurainia and Lepidium are known to have been prehistoric foods. Battillo (2017) determined that mustard seeds were eaten. The trichomes show that mustard greens were also eaten and provided a source of vitamins A and C, a good source of iron and supplemental source of folate (Battillo 2017). Turkey Pen Ruin coprolites are optimally preserved. Arthropod and fungal decomposers are absent. The samples responded well to rehydration and screening such that there was a complete liberation and separation of microscopic remains.

\section{Bighorn Cave, Arizona}

Bighorn Cave is located in the Black Mountains of Arizona, Basin and Range Province, approximately $30 \mathrm{~km}$ east-northeast of the point where the California-Nevada border intersects with Arizona (Geib and Keller 2002). The cave is a large rock shelter and perennial water is located within walking distance of the cave. Temporary water would have been available from an arroyo that drains Cobra Canyon. The surrounding environment exhibits a diversity of plant life due to its ecotonal setting at the junction of three major environments: the Sonoran Desert, the Mojave Desert, and the Great Basin. This diversity is typical of the region's mountain ranges having distinct plant communities defined by elevation gradients. The cave is located at 938 masl. Thus, different plant communities can be reached by walking higher or lower from the site.

The remains date from the Archaic Period to late prehistoric times in three components. Coprolites were recovered from levels dated to 
components I, II, and III. Component I dates to the Late Archaic, between 1200 and 400 BC. Component II dates to the Terminal Archaic, between $200 \mathrm{BC}$ and $\mathrm{AD}$ 100. Component III represents the Formative Period and dates from AD 550 to 1200. The Archaic components represent hunter gatherer people. Component III represents agricultural times. However, the evidence of agricultural foods was meager.

Coprolite 4 from Bighorn Cave, Arizona (Reinhard et al. 2003) represents marginally good preservation (Fig. 4). The major challenge with this sample is an infiltration of sand and ash from the matrix from which it was recovered. However, the separation of microfossils was good and the abundance of prickly pear phytoliths is obvious. An interesting detail of the cactus tissue is the presence of wide-band tracheids, typical of cactus xylem (Bobich and Nobel 2001; Perrotta and Arambarri 2018). Ring tracheids are found in the xylem cells of a great variety of vascular plants. However, in cactus, the rings are especially thick due to the biomechanics inherent in the cactus adaptations to xeric environments (Fig. 4).

We are digressing from analysis of microscopic botanical remains to address taphonomy of bones in coprolites. Fragmented bone with rounded fractures may be construed as postdepositional alteration due to abiotic or contextual taphonomic factors. Such bones occur in high prevalences in coprolites. In his review of dietary components of coprolites from the arid regions of North America, Reinhard (1992) found that small animal bones from mammals, fish, and reptiles were prevalent across the region. Hunter-gatherers consumed more small animals than agricultural people, but small mammals were a constant natural resource across time and subsistence strategies. A detailed analysis of samples from two Archaic sites revealed that the archeological harvesting and preparation of rabbits and rodents paralleled that documented by ethnographers (Reinhard et al. 2007). Continued analysis shows that larger animal bone, including domestic dog, was consumed just over 9000 years ago (Tito et al. 2011). Surprisingly, even bones from a poisonous snake were eaten with a whole rodent between 1460 and 1528 years ago (Sonderman et al. 2019). The use of small animals as food is also evidenced by a mummy (Verostick et al. 2018). The mummified colon contents contained grasshoppers, small fish, snake, bat, recently hatched bird, white-footed mouse, and pocket gopher. All three of these recent studies focused on human 


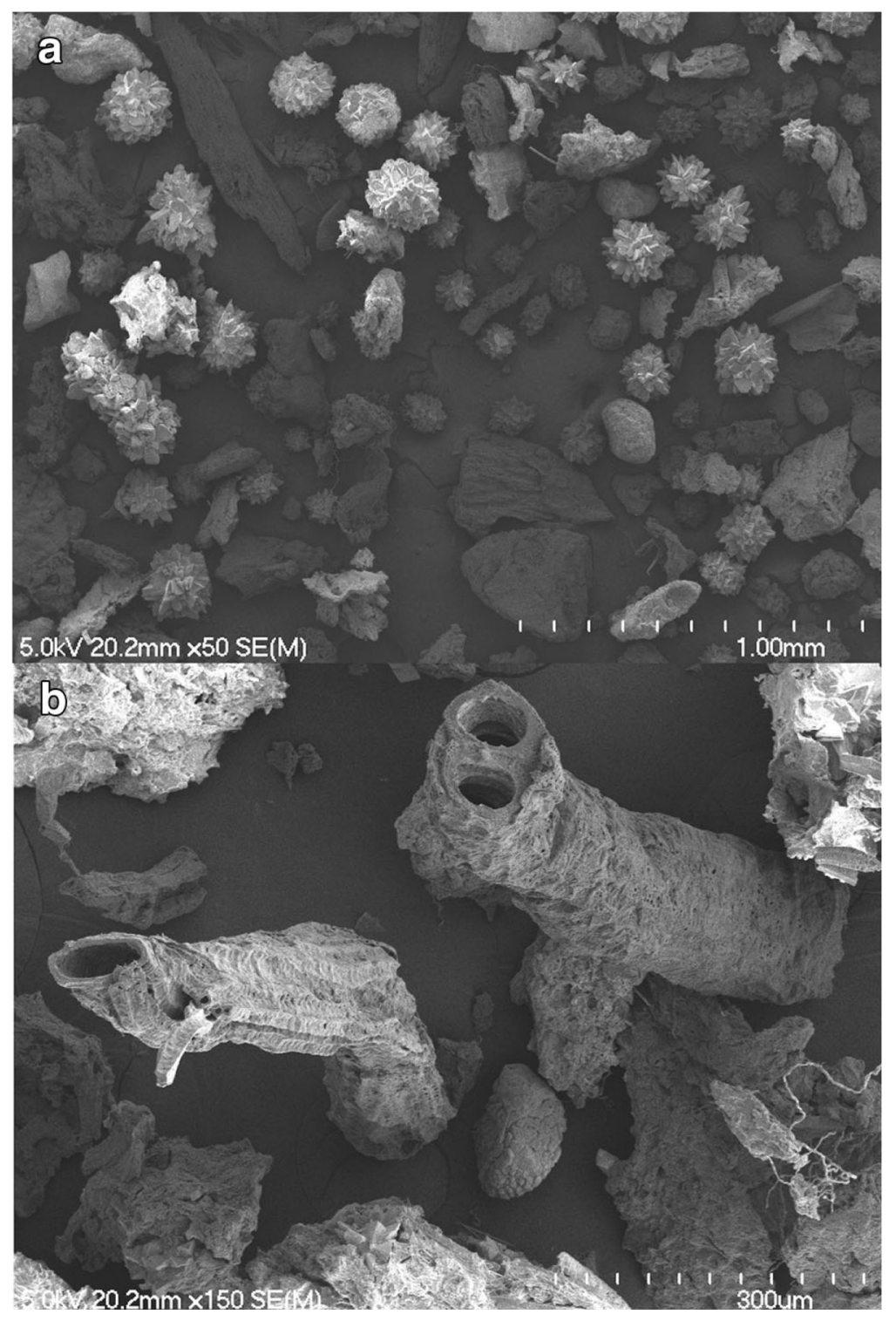

Fig. 4 Bighorn Cave coprolite 4 (Reinhard et al. 2003) residues were readily rehydrated and screened into discrete microfossils. A shows an abundance of prickly pear calcium oxalate phytoliths. However, among the phytoliths are fragments of woody tissue and sand. The sand, and probably woody fragments, are likely contaminants from the surrounding cave matrix. B shows cactus xylem tissue. Note the wide tracheid rings that are stacked to form the conductive tubes from the xylem. These are to provide strength to the cactus structure. 
coprolites from the Lower Pecos Canyonlands. At the northern range of the Great Basin, multidisciplinary analysis of Paisely Caves coprolites shows that the first adaptation to the region included small animals as food (Shillito et al. 2018). These authors review the evidence of small bone coprolite inclusions which show a continuity in small animal resource use through time in the region.

For coprolite analysts, the finding of fragmented shards of bone in coprolites provokes contemplation of the mechanism by which bone passes through the intestinal tract without causing harm. Considering this issue, Reinhard wrote, "Occasionally the bone from coprolites is fragmented into such small pieces that the bones were probably fractured before consumption. Also, digestion dissolves bone. Experiments with the consumption and defecation of small fish bone shows that a large share of bone is dissolved in the intestine (Jones 1986). Mammalian bones can also be fully digested as shown by Crandall and Stahl (1995)" (Reinhard et al. 2007: 417). To assess the alteration of bone through the intestinal tract, we selected bone fragments from a Bighorn Cave coprolite curated in the Pathoecology Laboratory for SEM imaging (Fig. 5).

To illustrate the nature of microscopic bone, specimens from processed macroscopic remains were taken from sample 12 dating to Formative times, cal. AD 550 to 1200. In addition to bone, analysis showed that plant foods were eaten including prickly pear pad, Agave/Yucca and pigweed/goosefoot greens (Reinhard et al. 2003). The bones, imaged in Fig. 5, are small fragments ranging from 1 to $2 \mathrm{~mm}$ in length. The edges of the fragments are eroded and smoothed. The surface of the cortical bone exhibits parallel cracks. The trabecular bone shows eroding and smoothing of the fractured edges with good preservation of tiny pores. The images support the proposition that the bones were heavily fragmented before consumption, perhaps altered superficially when small animals were cooked and then further altered by mastication and digestion.

Ethnographers specified the methods of cooking small mammals that would produce bone fracturing similar to that visualized in Fig. 5.Woodrats were food for the Yaqui (Spicer 1954: 49) and the tribes of the lower Colorado River (Castetter and Bell 1951: 217). Rabbits were killed by clubbing after being surrounded in drives. Some of the rabbits were prepared for storage until winter when food was scarce. The 


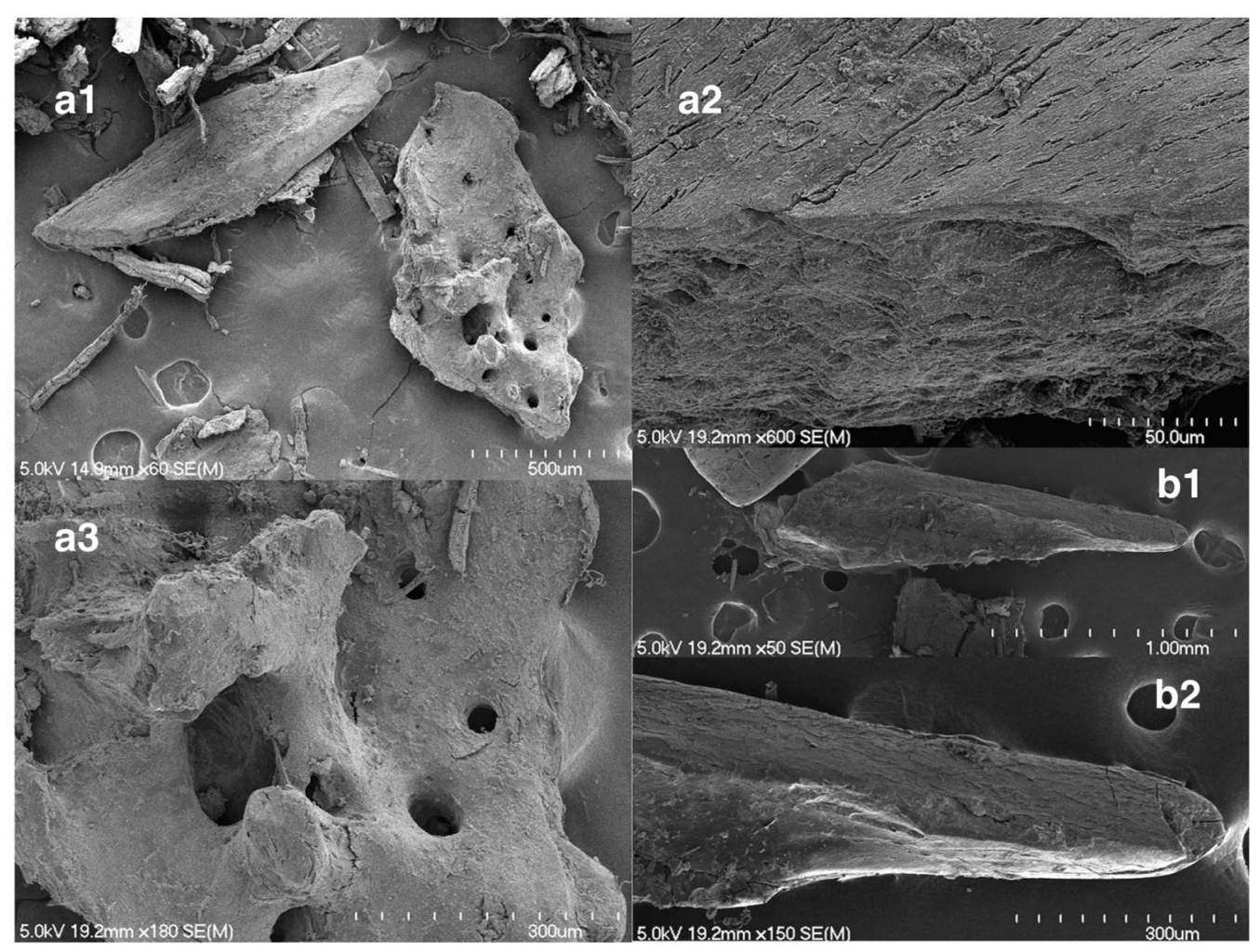

Fig. 5 Images of bones separated from macroscopic remains. Only via SEM is it possible to image the microscopic preservation of the bones having passed through a digestive tract. A1-3 show two bone fragments at various magnfications. Overall, the bone fragments show rounding and erosion. A2 shows section through an existing fracture. Note that the cortical surface of the bone exhibits parallel cracks from processing digestion or post depositional desiccation. A3 demonstrates that the exposed trabecular bone is altered, but the overall the appearance looks much like a normal, porous bone. B1-2 shows a sharp bone fragment, but at high magnification it is clear that the sharp edge has been rounded.

carcasses were dried as documented for the Northern Paiute (Fowler and Liljeblad 1986). When needed, entire carcasses with bones were pounded into fragments to make soup. The Yumans valued wood rat bones and saved, pounded, and ate them (Castetter and Bell 1951: 217). Sparkman (1908) noted that Luiseño people cooked small mammals by broiling on coals. Rabbits were sometimes cooked in earth ovens, and the meat and bones were mashed in a mortar before eating. Therefore, the appearance of Fig. 5 remains indicates a prehistoric origin for these manners of small mammal preparation as noted by ethnographers. 
Considering that the Bighorn Cave coprolites were in generally good preservation, we believe that the alteration of the bone is due partly to preparation of small animals for consumption. However, further alteration occurs with mastication and exposure of bones liberated in the digestive tract to chemical alteration.

\section{Dust Devil Cave, Utah, and small seed preparation}

The senior author's first experience in the analysis of coprolites was with the Dust Devil Cave collections (Reinhard et al. 1985). These coprolites were heavily infiltrated with sand causing a significant taphonomic issue. Small seeds were a main component. For this analysis, we used SEM to resolve the seed fragments to look for taphonomic evidence of postdepositional erosion. In reviewing the samples, curated in the lab before this analysis, Dust Devil Cave coprolites are very sandy.

The origins and expansion of small seed foraging have been researched by several scholars (Rhode et al. 2006; Geib and Jolie 2008, 2010; Reinhard et al. 1985). The shift to small seed gathering is viewed as a critical innovation marking the end of the Paleoarchaic and the beginning of the Archaic. Archaic subsistence is based on broad-spectrum hunting/gathering. In the arid west of North America, some debate centered on whether this important dietary transition initiated in the Great Basin or the Colorado Plateau. Geib and Jolie (2008) presented data that indicated older small seed subsistence on the Colorado Plateau. They verified this with Accelerator Mass Spectrometry (AMS) radiocarbon dating of dietary inclusions from Dust Devil Cave coprolites (Geib and Jolie 2010). They inferred that early Holocene drying impacted the Colorado Plateau before the Great Basin and that this climate change spurred the innovation of broad spectrum plant collection. For seed collection, technological innovations included ground stone food processing and coiled baskets for collection and parching.

Because of the importance of the transition to ground seed, this could be a key horizon for gut microbiome studies addressing diet change impact on gut bacterial communities. Thus, we felt that it would be informative to image samples from Dust Devil Cave to assess the taphonomic condition of the samples. Also, we can illustrate both 
the size of the seeds and the nature of flour made from grinding and parching the seeds. This site is on the Rainbow Plateau in southeastern Utah. In addition to a large recovery of grinding stones, 97 coprolites were analyzed for dietary remains (Reinhard et al. 1985; Van Ness 1986; Van Ness and Hansen 1996). Many coprolites contained goosefoot seeds of the genus Chenopodium. The seeds were parched and ground. The AMS dating of Dust Devil Cave samples shows that the transition to small seed consumption occurred just over 10,000 years ago and intensified later (Geib and Jolie 2010).

The coprolite imaged via SEM is Pathoecology Laboratory number 89 from Dust Devil Cave Stratum IVa. The date range for coprolites from this stratum is 8400 to 10,200 calibrated $\mathrm{C}^{14}$ age. Figure $6 \mathrm{a}$ shows the result of the preparation of Chenopodium seeds. The fragmented seeds are nearly uniform in being ground to less than 0.25 $\mathrm{mm}$ in the shortest dimension. Figure $6 \mathrm{~b}$ shows an intact seed from the same coprolite and shows that the original size of the seeds was less than a millimeter in longest dimension. This illustrates the truly diminutive size of foods that were the focus of small seed gathering and the resulting flour derived from processing. The question regarding the effects of sand infiltration on ground seed is addressed in Fig. 6a. The edges of the seed fractures are distinct and sharp. This indicates that they were not eroded by postdepositional processes. Note in Fig. 6a the rounded sand grains that infiltrated into the samples from the cave matrix. In our SEM experience, the only other post-Archaic site that has this focus on small seeds and refined milling technology is the Ancestral Pueblo occupation of Antelope Cave. Indeed, the noteworthy similarity represents a continuity of refined milling technology of wild seeds into Ancestral Pueblo times. Antelope Cave is located in Mojave County, Arizona, in the northwest corner of Arizona, about 25 miles southeast of St. George, Utah, on the Uinkaret Plateau (Reinhard et al. 2012). Between AD 700 and 1150, Ancestral Pueblo peoples used the cave as a seasonal camp to store artifacts, to gather local plants, and to hunt rabbits. The coprolites from the cave date to AD 1000-1150. The food milling technology used at Antelope Cave produced extremely fine flour and was focused in a diversity of plants (Reinhard et al. 2012). There are four principal processed plant foods represented in the Antelope Cave coprolites. These are maize, wild-grass caryopses, sunflower achenes, and cheno-am seeds. These 


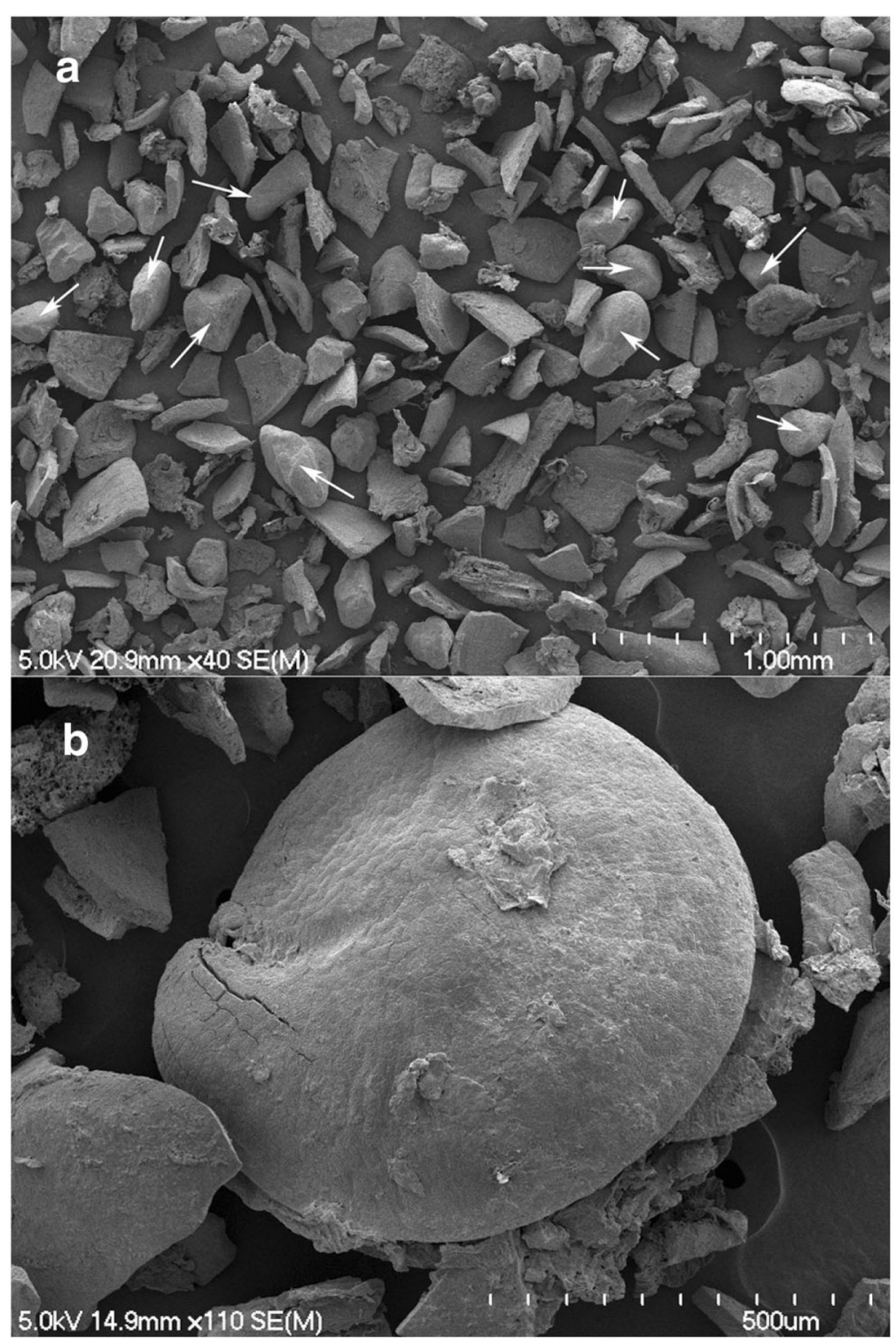

Fig. 6 The results of small seed milling are exhibited here. The upper image shows that the seeds are fractured to a very fine level, less than $0.25 \mathrm{~mm}$. Sand in the image is postdepositional. Arrows indicate some of the large sand grains. Sand of this size, exceeding $0.25 \mathrm{~mm}$, is relatively rare in coprolites. The lower image shows a split Chenopodium seed with typical morphology of that genus. The absence of plant epidermis, xylem and other delicate plant remains is noteworthy. This may be due to the consumption of seed cakes or to the washing of smaller remains from the samples by percolation over time as sand infiltrated into the sample matrix 
foods were ground to a fine flour, most of which were fragmented to a size less than $0.5 \mathrm{~mm}$. Thus, the small seed dependence that began at the beginning of the Archaic persisted in some areas long after agriculture was introduced.

Originally, it was speculated that the goosefoot seeds resulted from the use of "seed cake" at Dust Devil Cave (Reinhard et al. 1985:822). Later, researchers recognized that the evidence of small fractured rabbit bones indicated that rabbit carcasses were partitioned and eaten. The distribution of bones overlapped with that of Chenopodium, and also dropseed, seeds in Dust Devil Cave coprolites (Reinhard et al. 2007). Subsequently, this association was discovered in coprolite analysis from Antelope Cave, Arizona (Reinhard et al. 2012). A synthesis of food preparation was developed for Antelope Cave. This suggested that the seeds were ground, perhaps subsequent to parching, and then the seeds were stewed with rabbit meat. It is likely that this process was used at Dust Devil Cave.

\section{Fair preservation at an open site, Aztec ruins, New Mexico}

We are presenting the preliminary analysis of six samples from Aztec Ruins which is part of a very large and ongoing analysis of over 100 samples from Aztec and Salmon Ruins (Camacho et al. 2018a). These samples were selected from three rooms in Aztec Ruins. Based on criteria presented by Reinhard (2017), and including association with human specific pinworm eggs, these samples are of human origin.

Aztec Ruins is the subject of intense parasitological study (Camacho et al. 2018a; Camacho and Reinhard, this volume). It is an archeological complex of Ancestral Pueblo Great Houses located near the Animas River in Aztec, New Mexico. It is considered as a Chaco outlier community built in two phases, first at AD 1111 and then around $\mathrm{AD}$ 1118. Chacoans abandoned the site, and reoccupation occurred by a different population, thought to be from the Mesa Verde region.

Coprolites were recovered from excavation in three rooms. Twentyone coprolites were selected for analysis from the excavations of a trash deposit in room 219. From another trash deposit in room 225, 22 coprolites were selected for analysis. These rooms were in the West Ruin. From the East Ruin, a single coprolite was excavated from a kiva 
and was sampled for analysis. Rooms 219 and 225 were used simultaneously. Room 219 trash deposits date between 1182 and 1250 AD, and those of Room 225 date between 1185 and 1253 AD based on ceramic associations. Two grams of each sample was analyzed for dietary residue.

Decomposers were found in deposits from both rooms. Camacho and colleagues (Camacho et al. 2018a, b) found that mite infestation of the trash midden was more destructive to parasite eggs than nematode decomposers and insects such as flies and beetles. Fungal decomposition was also noted.

Aztec Sample 22 exhibits an abundance of fungal growth (Fig. 7). It also exhibits mite and nematode decomposers. There are 115 mites/ gram and 926 nematodes/gram of coprolite. The decomposition is evident, especially for the macroscopic remains. Indeed, almost no identifiable macrofossils were recovered from the sample (Table 1). Aggregates of decomposed plant food residue dominated the sample. However, and despite the diverse decomposer community, microfossils were abundant and reflect a bean leaf/squash flower association. For this sample, the tracheid lignin rings, tracheid helical spirals and xylem sections were found in anatomical association with bean (Phaseolus vulgaris) epidermis and trichomes (Table 2). Thus, the microscopic lignin remains signaled a meal that included bean leaves. The pollen analysis discovery of over 24,00o squash pollen grains per gram of coprolite is convincing evidence that squash blossoms were eaten (Table 3, Fig. 7). This sample reveals another newly documented aspect of prehistoric Pueblo diet, the harvest of maize truffles. Maize truffles, usually called corn smut, are the edible fruiting bodies of the fungus, Ustilago maydis. Although preliminary data from Pueblo coprolites indicated the use of maize truffles (Reinhard 2006), only recently has the dietary use been documented from Puebloans (Dahl 2009). Battillo's (2018) analysis of coprolites from Turkey Pen Ruin in Utah showed that maize truffles were a pervasive food for Basketmaker II peoples. Therefore, this sample shows that a meal of squash blossoms, bean leaves, and corn truffles was eaten.

It is noteworthy that $U$. maydis molecular data show a covariation with maize which shows that these two organisms mutually evolved as maize was domesticated and spread across the Americas (Munkacsi et al. 2008). 


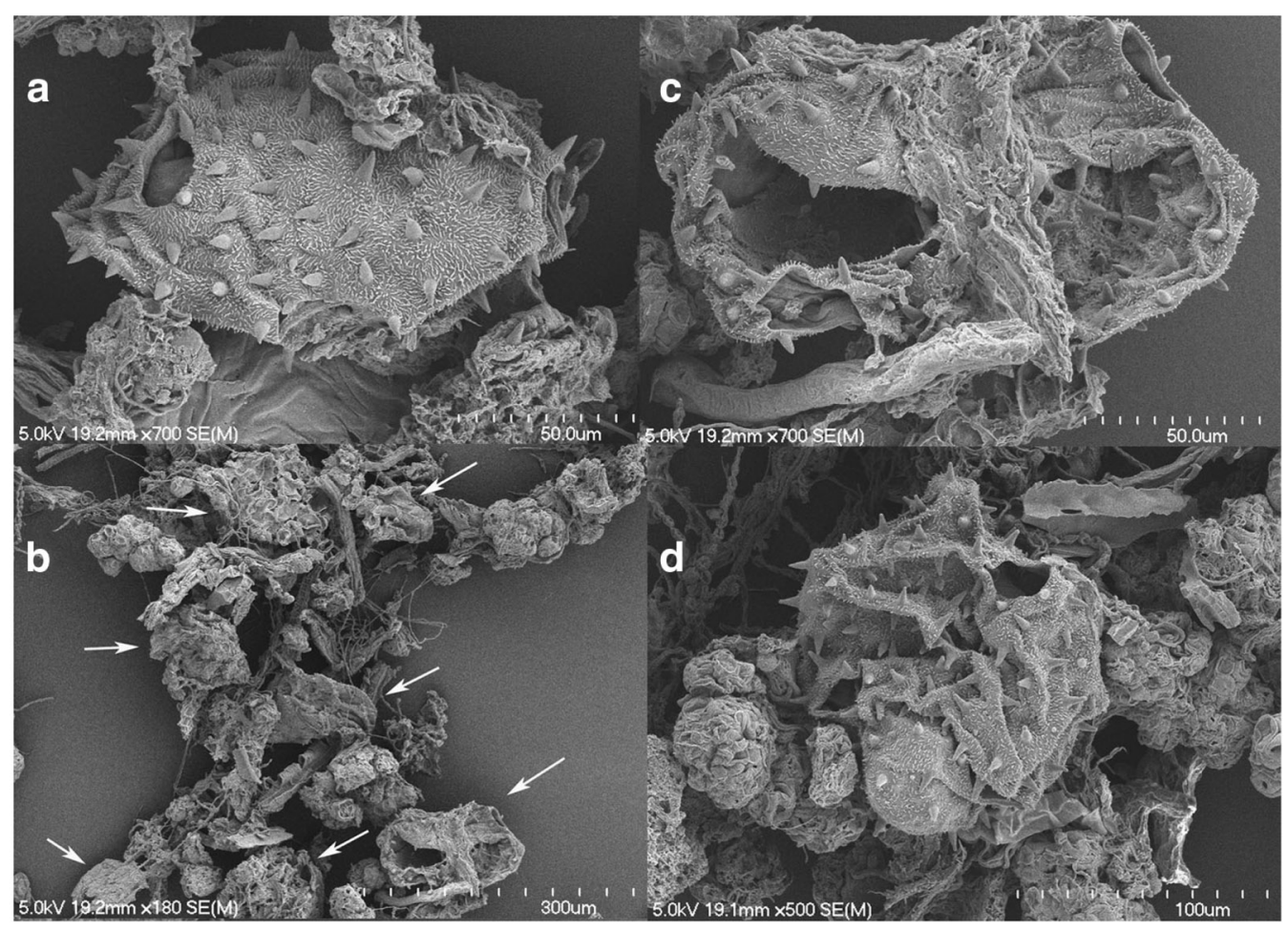

Fig. 7 Aztec 22 was an isolated sample from and Aztec East Ruins kiva that exhibited extensive fungal growth consisting of strings of hyphae. However, large dietary particles were visible in the fungal matrix. Pollen grains from squash, Cucurbita pepo were common in this sample. A fairly well preserved grain is shown in A with diagnostic pores and spines. B: A series of seven crumpled pollen grains (shown by arrows), some covered with fungal growth that obscures their morphological features. Note the clusters of fungal spores extending to the upper right corner of the image and another spore cluster immediately to the right of B. C: A close up of one of the grains with visible spines and pores. A single pollen grain is shown in D overlying a group of fungal fruiting bodies. The fungal growth occurred in the past. No active fungal growth was noted in the sample during processing.

Aztec 27 and 28were recovered from the same stratigraphic context in Aztec Ruins West, Room 225. Fly puparia were found in both samples, suggesting that there was an extensive decomposer community. Nematodes (49 per gram) and mites ( 8 per gram) were found in Aztec 27, and nematodes (16 per gram) were found in Aztec 28. Fine sand percolated into both specimens with moisture over time (Table 1). Because the samples were from the same stratigraphic context, a similar dietary profile might be expected. Both samples share traces of milled maize with substantial amounts of bean leaf trichomes, maize 
Table 1 Macroscopic remains from Aztec Ruins coprolites in grams. Two grams from each coprolite were processed and analyzed.

\begin{tabular}{|c|c|c|c|c|c|c|}
\hline Component & $\begin{array}{c}2 \\
\text { Room } \\
219\end{array}$ & $\begin{array}{c}18 \\
\text { Room } \\
219\end{array}$ & $\begin{array}{c}22 \\
\text { East Ruin } \\
\text { Kiva }\end{array}$ & $\begin{array}{c}27 \\
\text { Room } \\
225\end{array}$ & $\begin{array}{c}28 \\
\text { Room } \\
225\end{array}$ & $\begin{array}{c}29 \\
\text { Room } \\
225\end{array}$ \\
\hline Preservation state & Poor & Poor & Fair & Fair & Fair & Fair \\
\hline Aggregate of compressed fiber/debris, $<0.5 \mathrm{~mm}$ & 0.3 & & & & & \\
\hline Aggregate of compressed fiber/debris, $0.5^{-1} \mathrm{~mm}$ & 0.1 & & & & & \\
\hline Aggregate of compressed fiber/debris, 1-2 mm & 0.05 & & & & & \\
\hline Aggregate of compressed plant tissue with bean trichomes & Trace & & & & & \\
\hline Aggregate of dark debris, $0.5^{-1} \mathrm{~mm}$ & & & 0.02 & & & 0.1 \\
\hline Aggregate of finely masticated fiber, $1-2 \mathrm{~mm}$ & & & 0.01 & & & \\
\hline Aggregate, $<0.5 \mathrm{~mm}$ & & & & & 0.05 & \\
\hline Aggregate, $1-2 \mathrm{~mm}$ & & & & & & 0.07 \\
\hline Aggregates of granular debris, $>2.0 \mathrm{~mm}$ & & & & 0.01 & & \\
\hline Ceroid cactus seed & & & & & & Trace \\
\hline Charcoal, $>2.0 \mathrm{~mm}$ & & & & Trace & & 0.01 \\
\hline Cotton thread, $1-2 \mathrm{~mm}$ & Trace & & & & & \\
\hline Decomposer fly Puparia, $<0.5 \mathrm{~mm}$ & & & & & & 0.01 \\
\hline Decomposer fly puparia, $0.5^{-1} \mathrm{~mm}$ & & & & & & 0.01 \\
\hline Decomposer fly puparia, $1-2 \mathrm{~mm}$ & & & & & & 0.01 \\
\hline Decomposer fly puparia, $>2.0 \mathrm{~mm}$ & & & & Trace & Trace & \\
\hline Decomposer spider beetle, $<0.5 \mathrm{~mm}$ & & Trace & & & & \\
\hline Decomposer spider beetle, $0.5^{-1} \mathrm{~mm}$ & & Trace & & & & \\
\hline Eroded bone, $>2.0 \mathrm{~mm}$ & & 0.01 & & & & \\
\hline Eroded bone, $0.5^{-1} \mathrm{~mm}$ & & 0.02 & & & & \\
\hline Eroded bone, $1-2 \mathrm{~mm}$ & & 0.01 & & & & \\
\hline Fiber, $>2.0 \mathrm{~mm}$ & 0.01 & & & & & \\
\hline Fine fibrous matrix, $<0.5 \mathrm{~mm}$ & & & & 0.32 & & \\
\hline Fine fibrous matrix, $0.5^{-1} \mathrm{~mm}$ & & & & 0.01 & & \\
\hline Fine fibrous matrix, 1-2 mm & & & & 0.03 & & \\
\hline Fruit pericarp, $<0.5 \mathrm{~mm}$ & & & Trace & & & \\
\hline Fruit pericarp, $0.5^{-1} \mathrm{~mm}$ & & & Trace & & & \\
\hline Grass stem fragments & & & & & 0.04 & \\
\hline Insect fragments & & & & Trace & & \\
\hline Leaf fragments & & & & Trace & & \\
\hline Leaf fragments, $0.5^{-1} \mathrm{~mm}$ & & & Trace & & & \\
\hline Maize cupule fragment & & & & Trace & & \\
\hline Maize, $<0.5 \mathrm{~mm}$ & & & & 0.02 & & 0.24 \\
\hline Maize, $0.5^{-1} \mathrm{~mm}$ & & & & 0.01 & 0.02 & \\
\hline Maize, $1-2 \mathrm{~mm}$ & & & & & Trace & \\
\hline Masticated leaf fiber $\mathrm{w} /$ epidermis aggregates, $<0.5 \mathrm{~mm}$ & & & 0.31 & & & \\
\hline Portulaca seed & & & & & & Trace \\
\hline Sand, $<0.5 \mathrm{~mm}$ & 0.03 & & & 0.04 & 0.09 & 0.04 \\
\hline Sand, $>2.0 \mathrm{~mm}$ & Trace & & & & & \\
\hline Sand, $0.5^{-1} \mathrm{~mm}$ & & & & 0.07 & 0.05 & 0.01 \\
\hline Sand, 1-2 mm & & & & Trace & 0.01 & 0.01 \\
\hline Spiral trachieds, $<0.5 \mathrm{~mm}$ & & & & & 0.18 & \\
\hline Spiral trachieds, $0.5^{-1} \mathrm{~mm}$ & & & & & 0.10 & \\
\hline Squash seeds, $<0.5 \mathrm{~mm}$ & 0.10 & Trace & & & & 0.03 \\
\hline Squash seeds, $>2.0 \mathrm{~mm}$ & 0.08 & & & & & 0.11 \\
\hline Squash seeds, $0.5^{-1} \mathrm{~mm}$ & 0.10 & & & & & 0.03 \\
\hline Squash seeds, $1-2 \mathrm{~mm}$ & 0.07 & & & & & 0.03 \\
\hline Stem, $<0.5 \mathrm{~mm}$ & 0.05 & & & & & \\
\hline Terminal grass spike, $1-2 \mathrm{~mm}$ & Trace & & & & & \\
\hline Unidentified arthropod, $1-2 \mathrm{~mm}$ & Trace & & & & & \\
\hline
\end{tabular}


Table 2 Microscopic structure concentrations from Aztec Ruins coprolites in terms of number per gram of coprolite. Tracheid helical spirals, tracheid lignin rings, vessel sieve elements, and xylem sections are derived from xylem and phloem from plant vascular bundles.

\begin{tabular}{|c|c|c|c|c|c|c|}
\hline & $\begin{array}{c}2 \\
\text { Room } \\
219\end{array}$ & $\begin{array}{c}18 \\
\text { Room } \\
219\end{array}$ & $\begin{array}{c}22 \\
\text { East Ruin } \\
\text { Kiva }\end{array}$ & $\begin{array}{c}27 \\
\text { Room } \\
225\end{array}$ & $\begin{array}{c}28 \\
\text { Room } \\
225\end{array}$ & $\begin{array}{c}29 \\
\text { Room } \\
225\end{array}$ \\
\hline Preservation & Poor & Poor & Fair & Fair & Fair & Fair \\
\hline Bean trichomes & 191,667 & 68,750 & 147,500 & 82,015 & 34,768 & 15,777 \\
\hline Bean Epidermis w/ trichomes & & & 3750 & & & \\
\hline Grass epidermis & 1250 & & 1250 & & 12,417 & \\
\hline Long trichomes & 33,333 & & 1250 & & 14,901 & \\
\hline Macrosclereids from seeds & & & & & & \\
\hline Seed coat fragments & & $1,250,000$ & & & & \\
\hline Tracheid helical spirals & 208,333 & 50,000 & 261,250 & 202,420 & 444,536 & 37,621 \\
\hline Tracheid lignin rings & 41,667 & & 83,750 & 15,705 & 221,026 & 3641 \\
\hline Vessel sieve elements & 8333 & & & & & 1214 \\
\hline Xylem sections & 54,167 & 75,000 & 28,750 & 26,175 & 34,768 & 9709 \\
\hline
\end{tabular}

Table 3 Pollen and spore concentrations in terms of grains or spores per gram restricted to economic types from Aztec Ruins coprolites. Cheno-am refers to species in the family Amaranthaceae and the subfamily Chenopodioideae. Zea altered refers to expanded, thinned shreds of exine from degraded pollen grains.

\begin{tabular}{|c|c|c|c|c|c|c|}
\hline & $\begin{array}{c}2 \\
\text { Room } \\
219\end{array}$ & $\begin{array}{c}18 \\
\text { Room } \\
219\end{array}$ & $\begin{array}{c}22 \\
\text { East Ruin } \\
\text { Kiva }\end{array}$ & $\begin{array}{c}27 \\
\text { Room } \\
225\end{array}$ & $\begin{array}{c}28 \\
\text { Room } \\
225\end{array}$ & $\begin{array}{c}29 \\
\text { Room } \\
225\end{array}$ \\
\hline Preservation & Poor & Poor & Fair & Fair & Fair & Fair \\
\hline Cheno-am & & 105,897 & 3400 & 240,228 & 310,430 & \\
\hline Cleome & 2155 & 12,458 & & 28,502 & 198,675 & 48,544 \\
\hline Corn truffle & & & 961,538 & $2,524,430$ & $7,077,815$ & $2,870,146$ \\
\hline Cotton & & & 507 & & & \\
\hline Cucurbita Opercula & 10,776 & & 3378 & & & \\
\hline Cucurbita whole & 862 & & 24,662 & 8143 & & 7282 \\
\hline Poaceae, wild & & 12,458 & & & & 2427 \\
\hline Zea whole & 680,172 & 485,880 & 845 & 533,388 & 2483 & 82,524 \\
\hline Zea altered & 54,310 & 24,917 & 338 & 883,550 & 54,636 & 347,087 \\
\hline
\end{tabular}

truffles spores, and cheno-am pollen (Tables 2 and 3). The cheno-am pollen counts range into hundreds of thousands per gram and signal the consumption of polleniferous food such as pigweed or goosefoot foliage with buds (Reinhard et al. 1991, 2006). They differ in that sample 27 has macroscopic leaf fragments, fine plant fiber, and squash pollen (Fig. 7). This sample also has 1,416,938 maize pollen grains per gram of sample. The majority of the maize pollen is altered such that the grains expanded in size and burst. The fractured pollen appears as sheets of pollen exine that is the most abundant microfossil 
discovered (Fig. 8). This feature of consumed maize pollen suggests that pollen was harvested and prepared in a way that expanded and burst the grains. Further exploration of this hypothesis awaits experimental preparation of pollen from maize tassels. Sample 28 has a larger abundance of beeweed pollen. Not tabulated, sample 27 is the only Aztec specimen presented here that contains maize starch. We are not including starch images. Starch analysis is dependent on transmitted light and polarized light microscopy. The internal hila of starch grains can be seen with transmitted light. Polarized light reveals the interference crosses cause by the refractive nature of starch structure. SEM shows only the surface structure.

Despite sharing the same archeological context, the samples represent distinct meals. Sample 27 represents a meal composed of maize pollen, squash blossoms/buds, milled maize kernels, bean leaves, maize truffles, and cheno-am greens. Sample 28 shares milled maize kernels, bean leaves, maize truffles, and cheno-am greens, but has an increase of beeweed (Cleome spp). It is of interest that when maize pollen is screened from the microremains, truffle spores are the most abundant microfossil type (Fig. 9). Importantly, Battillo (2018) found that $U$. maydis spores are too small to resolve with most light microscopes and so numerous that simply quantifying them is a challenge. Figure 9 is the first image of $U$. maydis spores from coprolite context.

Sample 29 was recovered in a separate context than 27 and 28 in room 225. Mites (6 per gram) and fly puparia were documented in this sample. Portulaca (purslane) and Echinocereus cactus (hedgehog and other types) were found in the macroscopic remains with squash seeds (Table 1). Milled maize, ground to less than $0.5 \mathrm{~mm}$ in size, was also found. Light microscopy was used to quantify xylem strands and bean trichomes (Table 2). Microfossils including xylem strands, maize pollen, and bean trichomes found in SEM analysis (Fig. 10). Pollen analysis shows that beeweed, maize truffle, and processed maize pollen were eaten (Table 3). This is an eclectic meal of wild and domestic plants.

These preliminary data from the East Ruin Kiva and room 219 show a pattern of Ancestral Pueblo subsistence that has not been documented before. The use of bean foliage, rich in trichomes, signals that beans were used as a source of greens. Maize truffles were an important source of nutrition that had many health benefits as summarized by Battillo (2018). Although expanded and shredded maize 


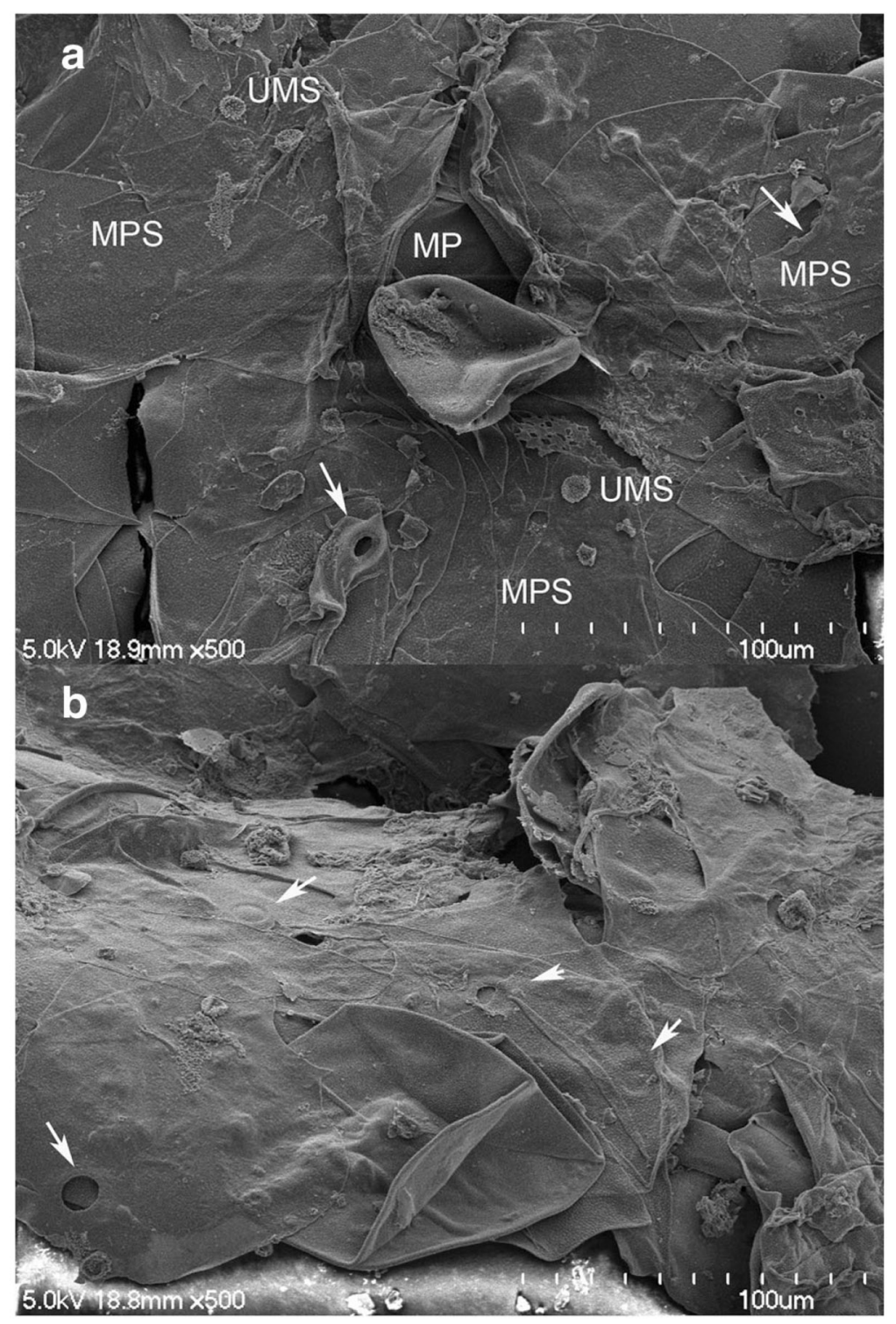

Fig. 8 AZTEC 27: The screened microscopic remains from this sample were almost completely composed of flattened, bursting maize pollen grains. A: A well preserved maize pollen grain (MP) lies on sheets of pollen walls that remain from maize pollen that was swelled passed the point of bursting (MPS). Also present are the tiny spores of maize truffle, Ustilago maydis (UMS). B: A close up of maize pollen sheets. Fortunately, the annulated pores of the deformed maize pollen were recognizable (arrows) and allowed for quantification of the number of maize pollen per gram in the sample. 


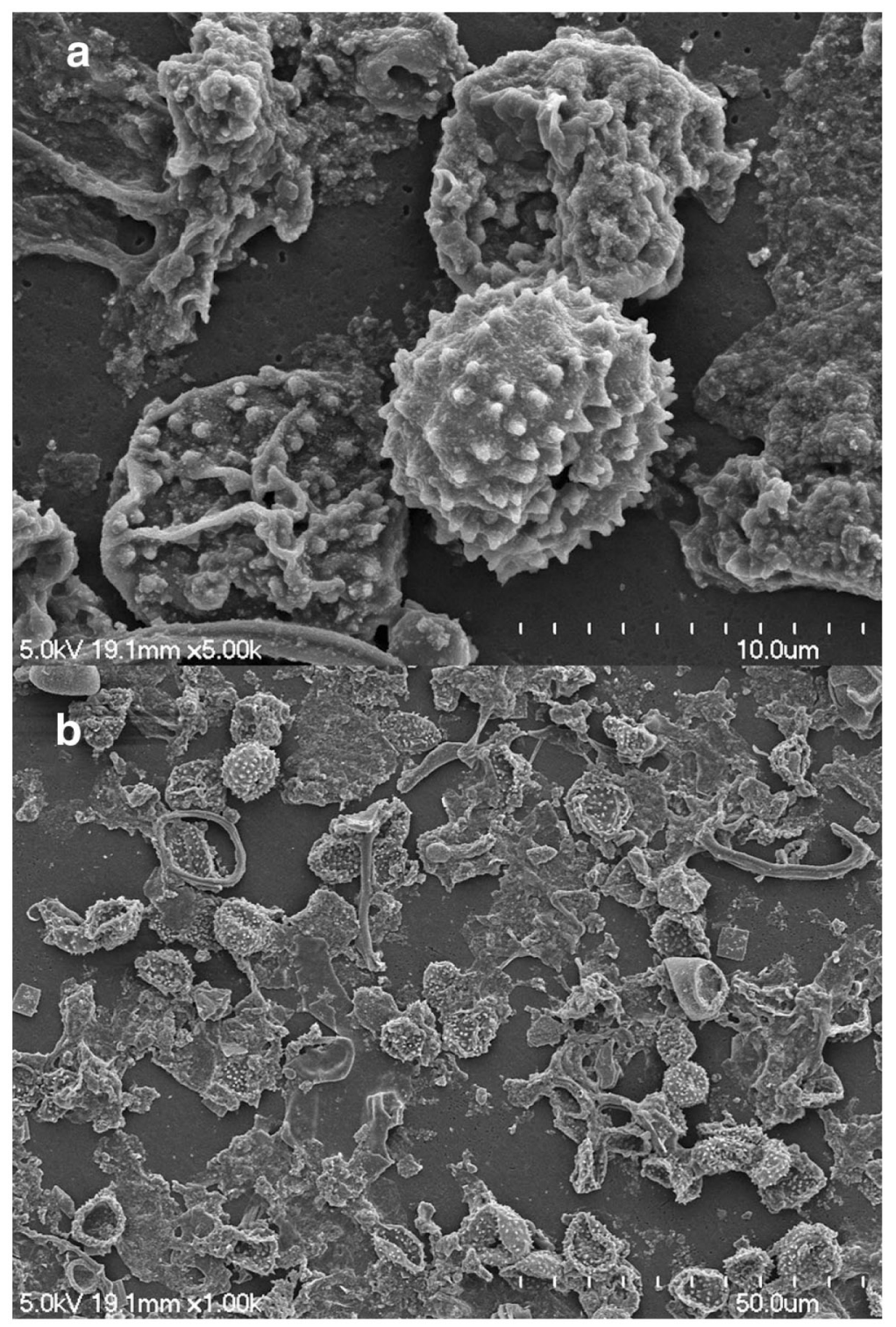

Fig. 9 AZTEC 28 spores of maize truffle, Ustilago maydis, were the most abundant identifiable microfossil in many samples. Only with SEM were we able to obtain sufficient resolution to identify these tiny spores (A). B : The abundance of the spores is illustrated by the large numbers visible.

pollen had previously been recognized (Reinhard et al. 2006), the SEM analysis shows that the pollen was processed in a way that expanded the exine pollen wall to the point that the grains were shattered into exine sheets. Overall, broken pollen could have been consumed with polleniferous, maize-based foods such as stews as 


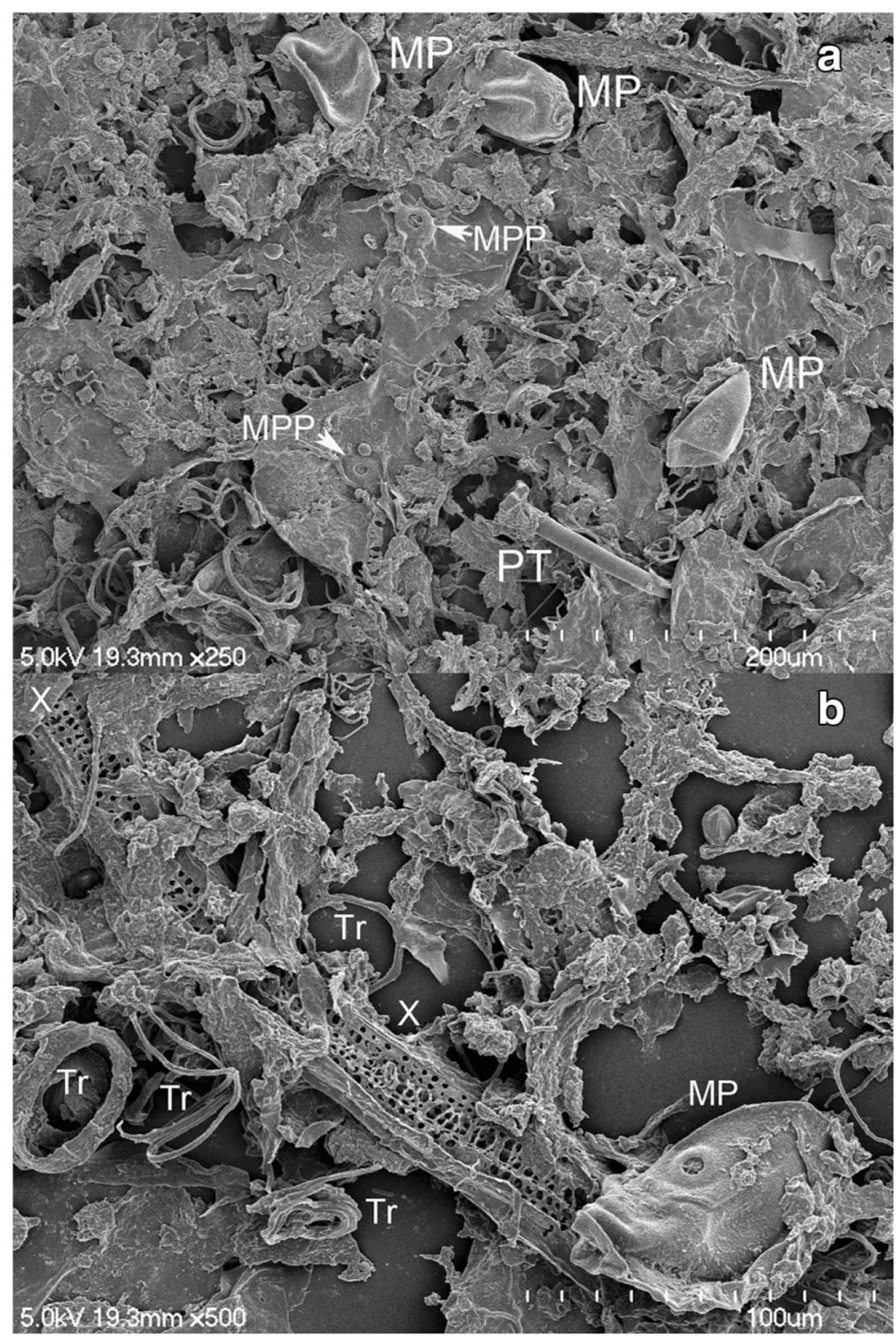

Fig. 10 AZTEC 29: A: A typical Aztec Ruins collection of microfossils recovered through a $250-\mu \mathrm{m}$ mesh screen. Maize pollen is evident ranging from good condition (MP) to flattened sheets. Some pollen have an inflated appearance, but the annulated pores are still evidence (MPP). Bean leaf hairs (PT) are also present. B: A closer look at the typical stem and leaf vascular cell remains from the samples. A long strand of xylem tissue (X) passes through masses of unraveled spiral tracheid wall thickenings (Tr). A well-preserved maize pollen (MP) is in the lower right of the image.

suggested by Sutton and Reinhard (1995). The highest concentrations of maize dominated by intact grains may signal ingestion of corn silk as suggested by Williams-Dean (1986). 


\section{Poor preservation at an open site, room 219 Aztec ruins, New Mexico}

Aztec sample 18 hosted a rich decomposer fauna including mites (Camacho et al. 2018a), flies represented by puparia and beetles represented by exoskeleton (Table 1). Mites were present at 56 mites/ gram (Fig. 11). Of $2.0 \mathrm{~g}$ of coprolite processed for analysis, only 0.04 $\mathrm{g}$ of identifiable material was found macroscopically. These included bone fragments and squash seeds. The vast majority of the remains decomposed to fragments of material lacking botanically recognizable form. These microscopic particles passed through the quarter millimeter mesh to be captured with the microscopic remains. These remains formed an organic milieu that coated the larger, discernable microfossils (Fig. 12). Some discernable plant remains, such as stem fragments, many seed fragments, and trichomes, passed through the screen. With light microscopy, these more durable remains were quantified and it is clear that bean leaves were eaten. The majority of squash seeds decomposed into microscopic fragments that were identified with light microscopy.

Aztec sample 2 exhibited a rich decomposer community with 1593 mites per gram of sample (Camacho et al. 2018a). The macroscopic remains are dominated by aggregates of mostly decomposed fibers and compressed aggregates of fibers. Only the most durable remains, fragmented squash seeds, were identifiable. Microscopic analysis showed evidence of bean leaf consumption in the form of bean epidermis with trichomes, separate trichomes, and vascular plant structures including tracheid lignin rings, tracheid helical spirals, xylem sections, and vessel sieve elements (Fig. 13). These microscopic particles numbered over a half million. Some grass epidermis was also found. Pollen data indicated that maize tassels were harvested for pollen. Flowers or buds of squash and beeweed were also eaten. Interesting observations include the fact that the maize pollen was fractured into large sheets. This was also observed in Aztec sample 27. It is clear that the gathered pollen was prepared in a way that expanded the pollen size to the point that the exine walls burst. Microscopic particles lie on sheets of maize pollen walls (Fig. 13). The lesson learned from this sample is that lignin and sporopollenin microfossils preserve in recognizable form, even in samples that have undergone extensive decomposition. 


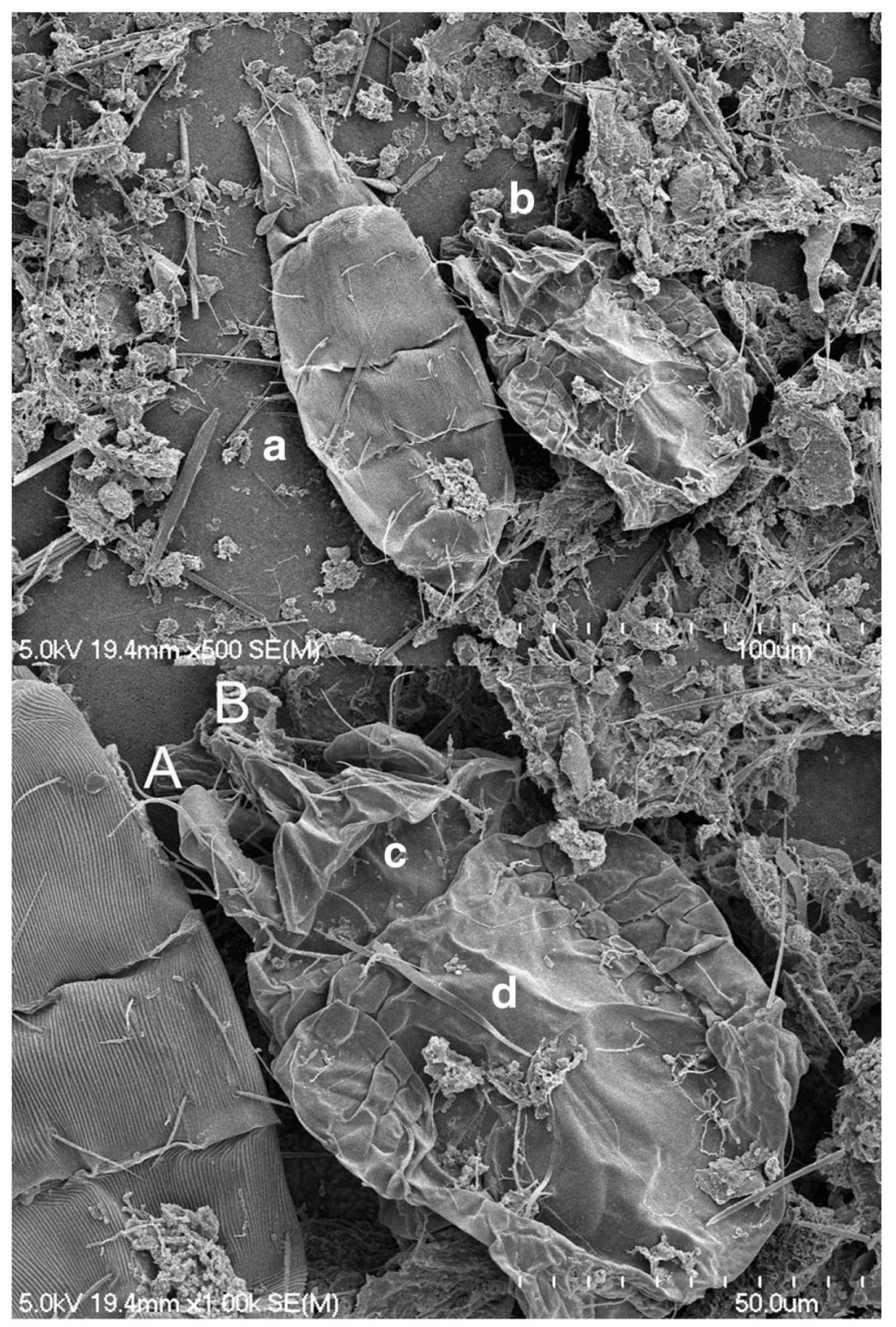

Fig. 11 AZTEC 18: Taphonomy studies of Aztec Ruins coprolites showed that a diverse decomposer community infested the samples in the days and weeks after deposition. These included flies, beetles, mites, nematodes, fungi, and probably bacteria. The upper image shows mite remains overlying decomposed plant material and seta from and insect. The insect seta is labeled A. The anterior of a mite is labeled $B$ in the upper image. The lower image is a close up of the mite and shows some anatomical features including palps (A), chelicerae (B) capitulum soft cuticle (C), and scutum (D). 


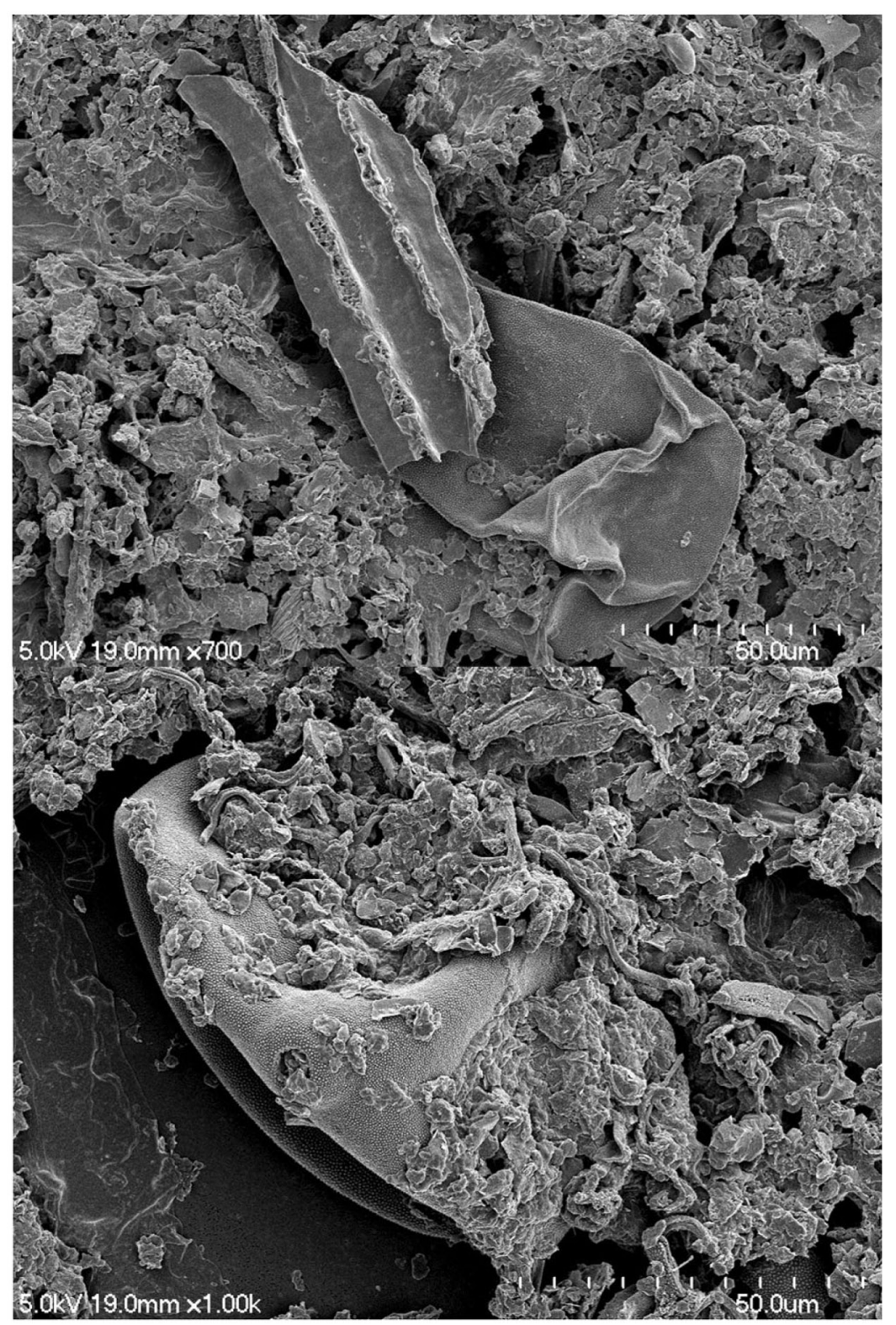

Fig. 12 AZTEC 18: Decomposition rendered the majority of the remains of this sample to a mass of decomposed plant tissue. The fine particles that resulted from decomposition obscured the features of microfossils. In the upper image, a maize pollen grain has been obscured by a stem fragment and finer unstructured particles. Below, a more magnified view of a different pollen grain obscured by unstructured particles as well as cellulose strands. 


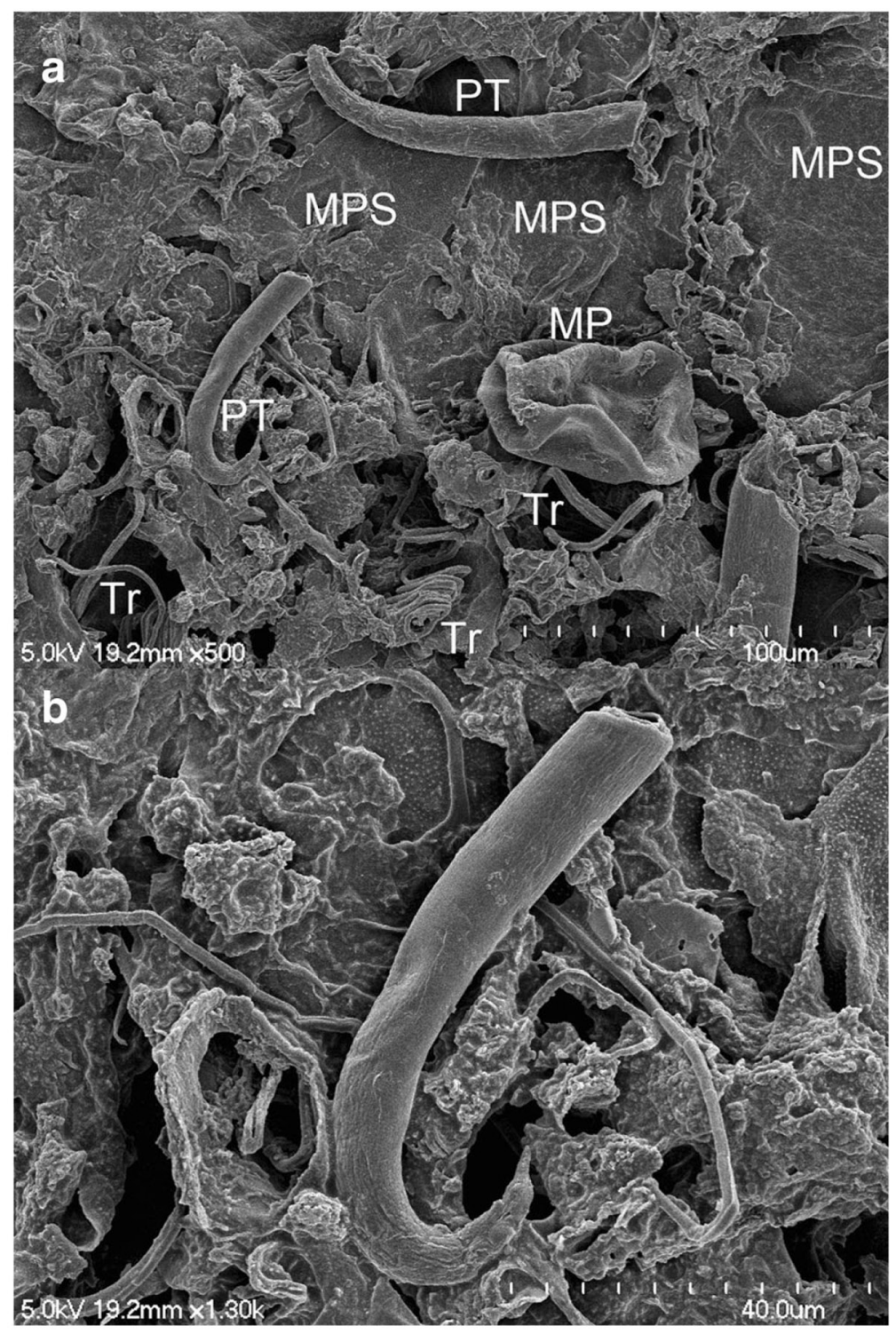

Fig. 13 AZTEC 2: These images show botanical microfossils that are relatively well preserved, although food processing has deformed maize pollen grains. A: Observe that the whole maize pollen grain (MP) is lying on a mat of flattened maize pollen sheets (MPS). These sheets are what remains of pollen grains that expanded, burst, and shredded. Very common in these samples were Phaseolus trichomes, or leaf hairs from bean plants (PT). Finally, tracheid spirals (Tr) are the thickened, supportive structure from plant vascular cells. B: A close up of a trichome on tracheids. 


\section{Conclusions from open site coprolite analysis-Aztec Ruins}

Sand percolation and calcium carbonate deposits show that moisture permeation was an issue common to Rooms 219 and 225. Biological agents were active in all three rooms. Thus, the preservation of dietary residues, especially at the macroscopic level, is less than ideal. These findings could have relevance to biochemical analysis since there was a definite interaction between the coprolite matrix and surrounding deposits. DNA was added by decomposers and also could infiltrate the sample from the trash matrix. These samples would be a less ideal choice for aDNA and ELISA analysis compared to ideal samples such as that representing Turkey Pen Ruins.

Despite the fair/poor coprolite macroscopic preservation at Aztec Ruins, heretofore unique dietary data were recovered. Aztec Ruins is the first Pueblo site that demonstrates the consumption of bean leaves. The curved trichomes, although present on the harvested bean pods, are much more abundant on leaf surfaces (Park et al. 1994). The find of epidermis articulated with bean trichomes is clear evidence that the leaves were eaten. Squash seeds and pollen, sometimes found in the same sample, suggests a double growing season or an extended season such that squash fruits were harvested at the same time as flower/bud availability.

The surprising coprolite evidence shows counter-intuitive plant use. First, maize pollen grains not associated with kernels were eaten. Second, bean leaves, not beans themselves, were harvested as greens. Although we believe that this represents a heretofore unrecognized use of bean greens as a common part of diet, we recognize that the used of greens could be an emergency meal (early in the growing season) rather than staple food. Finally, the abundance of squash pollen and seeds is new for Ancestral Pueblo coprolite analysis. Squash evidence provides simultaneous sources of flowers/buds and fruit. The analysis shows the three main Pueblo cultivated plants, maize, beans, and squash. However, the surprising revelation comes in the forms of food derived from the "triad". Bean leaf greens were eaten. Maize pollen and truffle fungus were important parts of the diet. Squash was more represented in pollen and seeds than any other Puebloan coprolite study to date.

Geib and Heitman (2015) describe ceremonies through which maize pollen could be ingested. One potential is the mixture of maize pollen 
into maize before grinding. They linked this ethnographically documented ceremony to the palynological literature regarding shredded versus whole pollen. The grinding of maize pollen with meal might result in shredded maize consumption with milled maize kernels. Samples 27, 28, and 29 have an association of maize pollen and milled maize. The pollen concentrations in terms of pollen grains per gram per samples are 1,416,938 for Aztec 27; 57,119 for Aztec 28; and 429,611 for Aztec 29. Interestingly, the proportion of shredded pollen is high for these samples, 62\% for Aztec 27; 96\% for Aztec 28; and $81 \%$ for Aztec 29. The maize pollen concentration in sample 22 is low and represents the background environment signal for maize as previously quantified for Ancestral Pueblo sites (Reinhard et al. 2006). Aztec 2 and 18 have no maize macroscopic remains. The pollen concentrations and percentages of altered pollen are 734,482 (7\%) for Aztec 2 and 510,797 (5\%) for sample 18. The contrast between these samples is striking and suggests that a taphonomic feature of shredded maize pollen could be milling pollen with meal preparatory to cooking and ingestion.

\section{The value of SEM imaging}

In their reviews of coprolite analysis, Riley (2010) and Battillo (2018) emphasized the developments and refinements in the analysis of coprolites for dietary residue. They reveal the methodological complexity applied to identify the wide spectrum of recoverable starch, cellulose, lignin, silica, calcium oxalate, chitin, and bone structures. This is dependent on knowledge of plant anatomy in turn based on plant dissection. They note the successful application of chemical tests, such a protein residue and sterol analysis, that confirm and add to our knowledge of prehistoric diet. Molecular biology has also added to the ability to discern foods in coprolites. We propose that SEM provides an excellent way to depict diverse dietary components in single images revealing the complexity of diet. In addition, SEM clarifies the condition of materials such as digested bone, altered pollen, and milled seed so that we can better understand the nature of prehistoric food preparation. Importantly, SEM allows researchers to gauge the nature and extent of taphonomic processes. This includes visualizing the fungal and invertebrate decomposers themselves and also 
showing the products of decomposition in fine resolution. From this small series of case studies, we can categorize the factors of decomposition at play for our sites.

\section{Factors of decomposition}

Table 4 lists the factors that affected the samples presented herein. The Dust Devil Cave sample was sandy and composed microscopically of granular, resistant structures such as Chenopodium seeds. The sample presented from Bighorn Cave also is composed primarily of granular dietary phytoliths but with matrix contaminants. The microremains also included cactus cladode elements. It is very likely that occasional water percolation dispersed smaller remains into the cave sediment while sand entered these specimens. We suggest that samples such as these have a lower biochemical information potential due to loss of fine matrix to the surrounding environment. In contrast, the Turkey Pen Ruins sample responded optimally to rehydration and separation of macroscopic from microscopic remains. The microscopic remains were not obscured by decomposition detritus. Similarly, the Hinds Cave sample exhibited excellent processing results. However, close examination of the microfossils shows encrustations of decomposition debris.

Table 4 Taphonomic factors that affected the information potential of the samples. It is noteworthy that fungal growth was a severe complication only in Aztec 22 East Kiva. Mites and nematodes signal decomposition environments that inhibited preservation of macroscopic.

\begin{tabular}{lcccc}
$\begin{array}{l}\text { Sample source/ } \\
\text { preservation }\end{array}$ & $\begin{array}{c}\text { Abiotic source } \\
\text { of sand }\end{array}$ & Anthropogenic & Contextual & Ecological \\
\hline $\begin{array}{l}\text { Hinds cave/good } \\
\text { Turkey Pen Ruins/good }\end{array}$ & & Latrine deposit & Shelter & Latrine flies \\
Bighorn Cave/good & Possible percolation & Midden deposit & Shelter & Spider beetles \\
Dust Devil Cave/good & Infiltration & Latrine deposit & Shelter & Shelter \\
Aztec 22 East Kiva/fair & Percolation & Trash deposit & Open site & Mites, nematodes, fungus \\
Aztec 27 Room 225/fair & Percolation & Latrine deposit & Open site & Flies, mites, nematodes \\
Aztec 28 Room 225/fair & Percolation & Latrine deposit & Open site & Flies, nematodes \\
Aztec 29 Room 225/fair & Percolation & Latrine deposit & Open site & Flies, mites \\
Aztec 18 Room 219/poor & Percolation & Latrine deposit & Open site & Flies, beetles, mites \\
Aztec 2 Room 219/poor & Percolation & Latrine deposit & Open site & Mites, nematodes \\
\hline
\end{tabular}


The samples from Aztec Ruin presented researchers with a processing challenge. Sample 18 was so degraded that our research group recovered $0.04 \mathrm{~g}$ of material macroscopically from the $2.0 \mathrm{~g}$ that were processed. The remains largely passed through the quarter millimeter mesh. These remains had lost the original anatomical structure and covered durable microremains, obscuring them. After acetolysis, recognizable pollen was recovered. "Aggregates" dominated or codominated the macroscopic remains for the other five samples. Simply stated, aggregates are masses of accumulations of various botanical remains that were compressed into inert materials. Such aggregates result from physiological compression and dehydration of chyme as digested material forms feces in the colon. Generally, laboratory rehydration and disaggregation disperses the aggregates. The fact that aggregates persisted in the open sites suggests that postdeposition taphonomic processes made the aggregate particles inert. Two factors are at play, fluid deposition of calcium carbonate throughout the coprolite and deposition of silica sand perolationg through perforations in the samples. The calcium carbonate was likely a result of occasional wetting of the deposits. The sand also percolated in from the surrounding matrix through small perforations made in the samples by decomposer organisms, especially beetles and flies. Sand was present in most of these specimens. For the "fair" category, the rehydration and disaggregation procedures separated seeds and leaf tissue into recognizable elements. The microfossils were relatively clean except for sample 22 which showed high fungal activity that bound the microremains in hyphae. Importantly, the pollen processing through acetolysis destroyed the fungal remains and released well-preserved pollen. Of the conditions summarized in Table 4, percolation and biological decomposition are the main threats to data integrity from coprolite analyses.

As molecular and ELISA approaches to coprolite study become more standard, triage assessment of preservation becomes necessary to determine which samples are most likely to retain biochemical signals from the organic milieu. There is a tendency to assume that open site samples are universally poorly preserved. However, studies of parasites and decomposers (Camacho et al. 2018a) and review of dietary data presented in this paper shows that the decomposition community can vary from room to room within the same archeological site. 
Similarly, preservation from geologically protected sites also varies. Therefore, we recommend that samples selected for molecular and immunoassay analysis be assessed for preservation potential by microscopy. SEM has enormous potential for defining biological decomposers, especially mites and fungi.

Acknowledgments The authors would like to acknowledge the Conselho Nacional de Desenvolvimento Científico e Tecnológico, CNPq (AMI, grant number 307932/20141) and the Fundação Carlos Chagas Filho de Amparo à Pesquisa do Estado do Rio de Janeiro, FAPERJ (AMI, grant number CNE 2/2016). The University of Nebraska School of Natural Resources provided logistical support. We especially thank the directorship and archeological staff of Aztec Ruins National Monument (U.S. National Park Service) for granting us permission, providing logistical support, and dating of the coprolite strata.

\section{References}

Battillo JM (2017) Supplementing maize agriculture in Basketmaker II Subsistence: dietary analysis of human paleofeces from Tsurkey Pen Ruin (42SA3714). Dissertation, Southern Methodist University.

Battillo JM (2018) The role of corn fungus in Basketmaker II diet: a paleonutrition perspective on early corn farming adaptations. J Archaeol Sci Rep 21:64-70. https://doi.org/10.1016/j.jasrep.2018.07.003

Beilstein MA, Al-Shehbaz IA, Mathews S, Kellogg EA (2008) Brassicaceae phylogeny inferred from phytochrome A and ndhF sequence data: tribes and trichomes revisited. Am J Botany 95: 1307-1327. https://doi.org/10.3732/ ajb.0800065

Black SL, Thoms AV (2014) Hunter-gatherer earth ovens in the archaeological record: fundamental concepts. Amer Antiq 79:204-226. https://doi. org/10.7183/0002-7316.79.2.204

Bobich EG, Nobel PS (2001) Biomechanics and anatomy of cladode junctions for two Opuntia (Cactaceae) species and their hybrid. Amer J Bot 88:391-400. https://doi.org/10.2307/2657103

Boyd CE (2003) Rock Art of the Lower Pecos (No. 8). Texas A\&M University Press

Boyd CE, Cox K (2016) TheWhite Shaman Mural: an enduring creation narrative in the Rock Art of the Lower Pecos. University of Texas Press, Austin

Boyd CE, Dering JP (1996) Medicinal and hallucinogenic plants identified in the sediments and pictographs of the Lower Pecos, Texas Archaic. Antiq 70:256275. https://doi.org/10.1017/So003598X00083265

BryantVM, Reinhard KJ (2012) Coprolites and archaeology: the missing links in understanding human health. In: Hunt A (ed) Vertebrate Coprolites. New 
Mexico Museum of Natural History and Science Bulletin 51. Albuquerque, pp. 379-387

Camacho M, Leles D, Santiago JD, Ramos RRC, Uchôa C, BastosOMP, Nunes VHB, de Souza SM, Araújo A (2016) Investigation of biodegradation in three different sediment cores from a shellmound (sambaqui) of Brazil, using Ascaris lumbricoides eggs as a model. J Archaeol Sci Rep 9:358-365. https://doi. org/10.1016/j.jasrep.2016.08.021

Camacho M, Iniguez A, Reinhard KJ (2018a) Taphonomic considerations on pinworm prevalence in three Ancestral Puebloan latrines. J Archaeol Sci Rep 20:791-798. https://doi.org/10.1016/j.jasrep. 2018.06.024

Camacho M, Araújo A, Morrow JJ, Reinhard KJ (2018b) Recovering parasites from mummies and coprolites: establishing an epidemiological approach. Parasit Vectors 11:248. https://doi.org/10.1186/s13071-018-2729-4

Castetter EF, Bell WH (1951) Yuma Indian agriculture; primitive subsistence on the Lower Colorado and Gila Rivers. University of New Mexico Press, Albuquerque

Crandall B, Stahl P (1995) Human digestive effects on a micromammalian skeleton. J Archaeol Sci 22:789-797. https://doi. org/10.1016/0305-4403(95)90008-X

Dahl K (2009) Corn Soot Woman's timeless lesson: eat your smut. Etnobiol 7:94-99

Danielson DR, Reinhard KJ (1998) Human dental microwear caused by calcium oxalate phytoliths in prehistoric diet of the lower Pecos region, Texas. Amer J Phys Anthropol 107:297-304. https://doi.org/10.1002/ (SICI)1096-8644(199811)107:3<297::AID-AJPA6>3.0.CO;2-M

Denevan WM (1995) 2 Prehistoric agricultural methods as models for sustainability. Adv Plant Pathol 11:21-43. https://doi.org/10.1016/ So736-4539(06)80004-8

Fowler CS, Liljeblad S (1986) Northern Paiute. In: D’Zaevedo WL (ed) Handbook of North American Indians 11. Smithsonian Institution, Washington, D.C., pp $435-465$

Fry GF (1977) Analysis of Prehistoric Coprolites from Utah. University of Utah Press, Salt Lake City

Fugassa MH, Reinhard KJ, Johnson KL, Vieira M, Araújo A (2011) Parasitism of prehistoric humans and companion animals from Antelope Cave Mojave County, Arizona. J Parasitol 97:862-867. https://doi.org/10.1645/GE-2459.1

Geib PR, Heitman CC (2015) The relevance of maize pollen for assessing the extent of maize production in Chaco Canyon. In: Heitmann CC, Plog S (eds) Chaco revisited: new research on the prehistory of Chaco Canyon, New Mexico. University of Arizona Press, Tucson, pp 66-95

Geib PR, Jolie EA (2008) The role of basketry in early Holocene small seed exploitation: Implications of a ca. 9,00o year-old basket from Cowboy Cave, Utah. Amer Antiq 73:83-102. https://doi.org/10.1017/S0002731600041299 
Geib PR, Jolie EA (2010) Direct evidence of early holocene dietary expansion on the Colorado plateau: interpreting the constituents of dated human feces. Presented at the 75th Annual Meeting, Society for American Archaeology, St. Louis.

Geib PR, Keller DR (2002) Bighorn Cave: test excavation of a stratified dry shelter, Mohave County, Arizona. Northern Arizona University, Flagstaff

Gonçalves MLC, Araújo A, Duarte R, da Silva JP, Reinhard K, Bouchet F, Ferreira LF (2002) Detection of Giardia duodenalis antigen in coprolites using a commercially available enzyme-linked immunosorbent assay. Trans Roy Soc Trop Med Hyg 96:640-643. https://doi.org/10.1016/S0035-9203(02)90337-8

Hammerl EE, Baier MA, Reinhard KJ (2015) Agave chewing and dental wear: evidence from quids. PLoS One. 10(7):e0133710. https://doi.org/10.1371/ journal.pone.0133710

Hampson J (2016) Embodiment, transformation and ideology in the rock art of Trans-Pecos Texas. Camb Archaeol J 26:217-241. https://doi.org/10.1017/ Sog59774315000505

Holden T (1990) The rehydration of coprolites using trisodium phosphate solution: colour reaction and smell. Paleopath Newsl 71:4

Isendahl C, Smith ME (2013) Sustainable agrarian urbanism: the low density cities of the Mayas and Aztecs. Cities 31:132-143. https://doi.org/10.1016/j. cities.2012.07.012

Jiménez FA, Gardner SL, Araújo A, Fugassa M, Brooks RH, Racz E, Reinhard KJ (2012) Zoonotic and human parasites of inhabitants of Cueva de Los Muertos Chiquitos, Rio Zape Valley, Durango, México. J Parasitol 98:304-309. https:// doi.org/10.1645/GE-2915.1

Jones AKG (1986) Fish bone survival in the digestive systems of the pig, dog, and man: some experiments. In: Brinkhuizen DC, Clason AT (eds) Fish and Archaeology: Studies in Osteometry, Taphonomy, Seasonality, and Fishing Methods. BAR International Series 294, Oxford, pp 53-61

Kirkland F, Newcomb WW (1996) The Rock Art of Texas Indians. University of Texas Press, Austin.

KoenigCW(2012) Burned rock middens, settlement patterns, and bias in the Lower Pecos Canyonlands of Texas. Thesis. Department of Anthropology. Texas State University-San Marcos

Lord KJ (1984) The Zooarchaeology of Hinds Cave (41 VV 456). Dissertation. The University of Texas Austin

Marlar RA, Leonard BL, Billman BR, Lambert PM, Marlar JE (2000) Biochemical evidence of cannibalism at a prehistoric Puebloan site in southwestern Colorado. Nature 407:74-78. https://doi.org/10.1038/35024064

McGregor R (2013) Basketry and other perishable arts. In: Shafer HJ (ed) Painters in prehistory: archaeology and art of the Lower Pecos Canyonlands. Trinity University Press, San Antonio, pp 153-170

Mock SB (2013) Painted pebbles: Lower Pecos women take charge. In: Shafer HJ (ed) Painters in Prehistory: Archaeology and Art of the Lower Pecos Canyonlands. Trinity University Press, San Antonio, pp 223-240 
Morrow JJ, Reinhard KJ (2016) Cryptosporidium parvum among coprolites from La Cueva de los Muertos Chiquitos (6oo-80o CE), Rio Zape Valley, Durango, Mexico. J Parasitol 102:429-436. https://doi.org/10.1645/15-916

Morrow JJ, Newby J, Piombino-Mascali D, Reinhard KJ (2016) Taphonomic considerations for the analysis of parasites in archaeological materials. Int J Paleopathol 13:56-64. https://doi.org/10.1016/j.ijpp.2016.01.005

Munkacsi AB, Stoxen S, May G (2008) Ustilago maydis populations tracked maize through domestication and cultivation in the Americas. Proc Roy Soc London B: Biol Sci 275:1037-1046. https://doi.org/10.1098/rspb.2007.1636

Park SJ, Timmins PR, Quiring DT, Jui PY (1994) Inheritance of leaf area and hooked trichome density of the first trifoliolate leaf in common bean (Phaseolus vulgaris L.). Can J Plant Sci 74:235-240. https://doi.org/10.4141/ cjps94-048

Perrotta VG, Arambarri AM (2018) Anatomía de los cladodios de Opuntia (Cactaceae) de la provincia de Buenos Aires, Argentina. Bol Soc Argent Bot 53:345-357 https://revistas.unc.edu.ar/index.php/BSAB/article/view/21310

Poinar HN, Kuch M, Sobolik KD, Barnes I, Stankiewicz AB, Kuder T, SpauldingWG, BryantVM, Cooper A, Pääbo S (2001)A molecular analysis of dietary diversity for three archaic Native Americans. PNAS 98:4317-4322. https://doi. org/10.1073/pnas.061014798

Rácz SE, Pucu E, Jensen E, Mostek C, Morrow JJ, Van Hove ML, Bianucci R, Willems D, Heller F, Reinhard KJ (2015) Parasitology in an archaeological context: analysis of medieval burials in Nivelles, Belgium. J Archaeol Sc 53:304-315. https://doi.org/10.1016/j.jas.2014.10.023

Raff JA, Reynolds AW, Turpin S, Rohland N, David R, Bolnick DA (2018) Paleogenomic investigations of the ancient inhabitants of the Lower Pecos region of Texas and Northern Mexico. Amer J PhysAnthrop 165:217-218. https://doi.org/10.1080/2052546.1991.11909637

Reinhard KJ (1985) Recovery of helminths from prehistoric feces: the cultural ecology of prehistoric parasitism. Thesis, Northern Arizona University.

Reinhard KJ (1988) Diet, parasitism, and anemia in the prehistoric Southwest. Dissertation, Texas A\&M University.

Reinhard KJ (1992) Patterns of diet, parasitism, and anemia in prehistoric west North America. In: Stuart-Macadam P, Kent S (eds) Diet, Demography, and Disease: Changing Perspectives on Anemia. Aldine de Gruyter, New York, pp 219-258

Reinhard KJ (2006) A coprological view of Anasazi cannibalism. AmSci 94:254262. https://doi.org/10.1511/2006.3.254

Reinhard KJ (2017) Reestablishing rigor in archaeological parasitology. Int J Paleopathol 19:124-134. https://doi.org/10.1016/j.ijpp.2017.06.002

Reinhard KJ, Araujo A (2015) Prehistoric earth oven facilities and the pathoecology of Chagas disease in the Lower Pecos Canyonlands. J Archaeol Sci 53:227-234. https://doi.org/10.1016/j.jas.2014.09.022

Reinhard KJ, Clary KH (1986) Parasite analysis of prehistoric coprolites from Chaco Canyon, New Mexico. In: Akins NJ (ed) A bioarchaeological approach to 
human burials from Chaco Canyon. New Mexico. National Park Service, Santa Fe, pp 214-222

Reinhard KJ, Danielson DR (2005) Pervasiveness of phytoliths in prehistoric Southwestern diet and implications for regional and temporal trends for dental microwear. J Archaeol Sci 32:981-988. https://doi.org/10.1016/j. jas.2005.01.014

Reinhard KJ, Ambler JR, McGuffieM(1985) Diet and parasitism at Dust Devil Cave. Amer Antiq 50:819-824. https://doi.org/10.2307/280170

Reinhard KJ, Hamilton DL, Hevly RH (1991) Use of pollen concentration in paleopharmacology: coprolite evidence of medicinal plants. J Ethnobiol 11:117-134

Reinhard K, Danielson M, Daniels DR, Miranda Chaves S (2003) Chapter 7: multidisciplinary coprolite analysis. In (PR Geib and DR Keller eds) Bighorn Cave: test excavation of a stratified dry shelter, Mojave County, Arizona. Bilby Research Center Occasional Papers 1. Northern Arizona University, Flagstaff, pp.135-152

Reinhard KJ, Edwards SK, Damon TR, Meier DK (2006) Pollen concentration analysis of Ancestral Pueblo dietary variation. Palaeogeogr Palaeoclimatol Palaeoecol 237:92-109. https://doi.org/10.1016/j.palaeo.2005.11.030

Reinhard KJ, Szuter C, Ambler JR (2007) Hunter-gatherer use of small animal food resources. Int J Osteoarchaeol 17:416-428. https://doi.org/10.1002/ oa.883

Reinhard KJ, Chaves SAM, Iñiguez AM (2008) Chloroplast aDNA in prehistoric Texas coprolites: evidence of contamination, medicine, and diet. J Archaeol Sci 35:1748-1755. https://doi.org/10.1016/j.jas.2007.11.013

Reinhard KJ, Johnson KL, LeRoy-Toren S,Wieseman K, Teixeira-Santos I, Vieira M (2012) Understanding the pathoecological relationship between ancient diet and modern diabetes through coprolite analysis: a case example from Antelope Cave, Mojave County, Arizona. Cur Anthropol 53:506-512. https://doi. org/10.1086/665923

Rhode D, Madsen DB, Jones KT (2006) Antiquity of early Holocene small-seed consumption and processing at Danger Cave. Antiq 80: 328-339. https://doi. org/10.1017/Soo03598X00093650

Riley T (2008) Diet and seasonality in the Lower Pecos: Evaluating coprolite data sets with cluster analysis. J Archaeol Sci. 35:2726- 2741. https://doi. org/10.1016/j.jas.2008.04.022

Riley T (2010) Assessing diet and seasonality in the Lower Pecos Canyonlands: an evaluation of coprolite specimens as records of individual dietary decisions. (Dissertation) Texas A\&M University. Shafer HJ (1975) Clay figurines from the Lower Pecos region, Texas. Amer Antiq 40:148-158. https://doi.org/10.1080/2 052546.1974.11908679

Shafer HJ (2013) Cultural and stylistic through time in the lower Pecos. In: Shafer HJ (ed) Painters in Prehistory: Archaeology and Art of the Lower Pecos Canyonlands. Trinity University Press, San Antonio, pp. 59-91. 
Shillito LM, Blong JC, Jenkins DL, Stafford TW Jr, Whelton H, McDonough K, Bull ID (2018) New research at Paisley Caves: applying new integrated analytical approaches to understanding stratigraphy, taphonomy, and site formation processes. PaleoAmerica 4(1):82-86. https://doi.org/10.1080/20555563.2017.1 396167

Sobolik KD, Gremillion KJ, Whitten PL,Watson PJ (1996) Sex determination of prehistoric human paleofeces. Amer J Phys Anthropol 101:283-290. https:// doi.org/10.1002/(SICI)1096-8644(199610)101:2<283::AID-AJPA10>3.0.CO;2-W

Sonderman EM, Dozier CA, Smith MF (2019) Analysis of a coprolite from Conejo Shelter, Texas: potential ritualistic viperous snake consumption. J Archaeol Sci Rep 25:85-93. https://doi.org/10.1016/j.jasrep.2019.03.032

Sparkman PS (1908) The culture of the Luiseno Indians (Vol. 8, No. 4). University Press, Berkeley

Spicer EH (1954) Potam, a Yaqui Village in Sonora. American Anthropological Association, Menasha Sutton MQ, Reinhard KJ (1995) Cluster analysis of the coprolites from Antelope House: implications for Anasazi diet and cuisine. J Archeol Sci 22:741-750. https://doi.org/10.1016/0305-4403(95)90004-7

Taylor A, Hutson JM, Bryant VM, Jenkins DL (2019) Dietary items in Early to Late Holocene human coprolites from Paisley Caves, Oregon, USA. Palynol. https:// doi.org/10.1080/01916122.2018.1530699

Tito RY, Macmil S, Wiley G, Najar F, Cleeland L, Qu C, Wang P, Romagne F, Leonard S, Ruiz AJ, Reinhard KJ (2008) Phylotyping and functional analysis of two ancient human microbiomes. PLoS One, 3(11), p.e3703. https://doi. org/10.1371/journal.pone.0003703

Tito RY, Belknap SL III, SobolikKD, IngrahamRC, Cleeland LM, Lewis CM Jr (2011) Brief communication: DNA from early Holocene American dog. Amer J Phys Anthropol 145(4):653-657. https://doi.org/10.1002/ajpa.21526

Tito RY, Kights D, Mecal J, Obregon-Tito AJ, Cleeland L, Fares N, Roe B, Reinhard KJ, Sobolik K, Aufderheide A, Foster M, Spicer P, Knight R, Lewis CM (2012) New insights from characterizing extinct human gut microbiomes. PLoS ONE 7(12):e51146. https://doi.org/10.1371/journal.pone.0051146

Turpin SA (1996) Painting on bones and other unusual media in the lower and transpecos region of Texas and Coahuila. Plains Anthropol 41: 261-272

Van Ness MA (1986) Desha complex macrobotanical fecal remains: an Archaic diet in the in the American Southwest. Thesis, Northern Arizona University.

Van Ness MA, Hansen E (1996) Archaic subsistence in Glen Canyon. In: Geib PR (ed) Glen Canyon Revisited, Anthropological Papers No. 119. University of Utah Press, Salt Lake City, pp 117-125

Verostick KA, Teixeira-Santos I, Bryant VM Jr, Reinhard KJ (2018) The Skiles Mummy: care of a debilitated hunter-gatherer evidenced by coprolite studies and stable isotopic analysis of hair. International Journal of Paleopathology. https://doi.org/10.1016/j.ijpp.2018.08.004

Williams-Dean G (1986) Pollen analysis of human coprolites. In: Morris DP (ed) Archeological Investigations at Antelope House. National Printing Office, Washington, D.C., pp 189-205 